\title{
Schuifelen op de rechterstoel
}

\section{De taak van de rechter in het Belgisch privaatrechtelijk procesrecht: een kwestie van moeten of mogen}

Willy van Eeckhoutte*

"Voor alle behandelde zaken heb ik het probleem [van recht te spreken: "il problema del giudicare"] opgelost. [...] Neem, bijvoorbeeld, de mis, het mysterie van de transsubstantiatie, brood en wijn die tot lichaam, bloed en ziel van Christus worden. De priester kan een onwaardig mens zijn, in zijn leven, in zijn gedachten, maar doordat hij de wijdingen heeft ontuangen, is het zeker dat het mysterie zich bij elke misviering voltrekt. Nooit, maar dan ook nooit, kan het gebeuren dat de transsubstantiatie niet plaatsvindt. Hetzelfde geldt voor een rechter als hij de wet toepast. Het is onmogelijk dat de gerechtigheid zich niet openbaart, niet transsubstantieert, zich niet voltrekt. Van tevoren kan de rechter piekeren, zich het hoofd breken, tegen zichzelf zeggen: je bent onwaardig, armzalig, belast met instincten, vertroebeld door gedachten, vatbaar voor elke mogelijke zwakheid en vergissing. Maar op het moment dat hij rechtspreekt niet meer. En daarna nog minder.'

De 'presidente della Corte Suprema' in L. SCIASCIA, Il contesto, voor het eerst uitgegeven in Milaan door Einaudi, in I97I en door Linda Pennings vertaald als De context, Amsterdam, Serana Libri, 2009, 96-97. De originele, Italiaanse, versie draagt de ondertitel Una parodia. In de Nederlandse uitgave is die weggelaten.

\section{Inleiding}

I. Dit Belgische rapport over de taak van de rechter van Daan Asser in het privaatrechtelijk procesrecht is de pendant van het Nederlandse rapport dat een titel draagt met een beperktere draagwijdte, nl. 'Ambtshalve toepassing van rechtsgronden door de Nederlandse rechter'. ${ }^{\text {I }}$

Mijn titel is ongetwijfeld te ruim voor wat ik in dit preadvies behandel. Zo heb ik het, om maar enkele voorbeelden te noemen, niet over de zgn. willige rechtsmacht van de rechter, over de opdracht van de rechter ten aanzien van buitenlands recht, over de wijze waarop hij geacht wordt op te treden in kort geding of ten aanzien van de overheid. Maar de titel van het rapport van mijn Nederlandse co-preadviseur is dan weer veel te beperkt. Zowel zijn als mijn rapport heeft het ook over de vraag wat de rechter mag en moet doen met de feiten die de partijen vermelden of aanvoeren

\footnotetext{
* W. van Eeckhoutte is advocaat bij het Hof van Cassatie en buitengewoon hoogleraar arbeids- en socialezekerheidsrecht aan de Universiteit Gent.

I Hieronder aangewezen als ASSER, met vermelding van de vindplaats.
} 
en met datgene wat zij vorderen. Dat is iets anders dan de ambtshalve toepassing van rechtsgronden. Die kunnen overigens niet alleen worden aangevuld, maar ook gewijzigd of vervangen.

2. Dit Belgisch preadvies is geschreven door iemand die alvast in twee, maar ongetwijfeld in nog veel meer, opzichten afwijkt van de persoon van de Nederlandse preadviseur: ik ben geen magistraat en geen processualist, maar een advocaat en een academisch en praktisch beoefenaar van het sociaal recht.

Ik neem aan dat sommigen dat als een ernstige handicap beschouwen (personen met een handicap nemen overigens in het sociaal recht een prominente plaats in). Maar ik denk dat die andere insteek (advocaat in plaats van magistraat) en achtergrond (geen focus op procesrecht) ook voordelen heeft. Ik zal dan ook trachten daarvan maximaal gebruik te maken. In mijn hoedanigheid van advocaat vind ik de beperkingen die het recht van verdediging stelt aan een te enthousiaste actieve en zeker aan een proactieve invulling van de rechterlijke taak, veel belangrijker dan de Nederlandse preadviseur-magistraat. Ik plaats dat daarom in een afzonderlijk deeltje (3.4.6). De meeste voorbeelden van het Nederlandse preadvies zijn erg privaatrechtelijk, al zijn er ook enkele uit het sociaal recht. Ik haal mijn voorbeelden bijna uitsluitend uit die rechtstak, die een prachtige osmose is tussen privaat- en publiekrecht. $^{2}$

3. Omdat het in de schoot van de Vereniging voor de vergelijkende studie van het recht van België en Nederland wel meer voorkomt dat de nochtans hoogst wenselijke voorafgaande overeenstemming tussen de auteurs over de afbakening en de structuur van hun preadviezen te wensen over laat, zeker als de preadviseurs een zo verschillend profiel hebben als in het vorige randnummer aangegeven, heb ik mij die overeenstemming a posteriori zelf opgelegd: ik heb, met toevoeging van randnummering waarvan ik een grote voorstander ben, zonder meer de structuur van het Nederlandse preadvies overgenomen, ook waar die wringt met de Belgische benadering of waar ik zelf een andere, naar mijn smaak zelfs betere, indeling zou hebben gemaakt. Dit maakt dit Belgische rapport wat geforceerd, maar dat is dan ook met opzet zo gebeurd. Dat nadeel weegt immers niet op tegen het voordeel dat dit preadvies echt de tegenhanger is van het Nederlandse. Ook inhoudelijk beoogt het af en toe al een tegenrede of repliek te zijn op het Nederlandse rapport en dat vanuit Belgisch (en een enkele keer ook wel persoonlijk) standpunt. Over de ambtshalve toepassing van EU-recht heb ik het niet, om niet in herhaling te vallen met wat de Nederlandse preadviseur daarover schrijft. ${ }^{3}$ Niettemin is dit rapport, door de koppeling naar het Nederlandse preadvies, langer geworden dan dit laatste, maar elk voordeel heeft nu eenmaal zijn nadeel.

\footnotetext{
2 Privaat- en publiekrecht zijn, met strafrecht, nog altijd de enige secties die de Vereniging voor de vergelijkende studie van het recht van België en Nederland wil erkennen. De prioriteit die dit preadvies geeft aan voorbeelden uit het sociaal-economisch recht, beoogt dan ook het uithangbord van de vereniging op een bescheiden wijze wat bij te schilderen.
} 
4. 'Language is the dress of thought'. ${ }^{4}$ En dat geldt zeker voor juristen. Om zijn gedachten precies en genuanceerd uit te drukken, moet een jurist zorgvuldig omgaan met de woorden die hij gebruikt. Dat reduceert weliswaar het aantal synoniemen en verhoogt het aantal woorden met een onderscheiden betekenis, maar leidt tot een meer verfijnde benadering. Als het om termen gaat, is less niet more, maar less.

Daarom vang ik dit preadvies aan met een lexicon van de voor het onderwerp meest relevante begrippen. ${ }^{5} \mathrm{Ik}$ weet dat een deel van de klassieke termen die ik gebruik, in de context van het onderwerp van dit preadvies volgens sommigen achterhaald of ouderwets zijn. Maar, om nog maar eens dr. Johnson van stal te halen, 'Language is only the instrument of science, and words are but the signs of ideas. I wish, however, that the instrument might be less apt to decay, and that signs might be permanent, like the things they denote'. ${ }^{6}$ Ik zal dus vertrekken van het klassieke jargon en waar het te pas komt, de decay vermelden.

In de context van de eigenlijke rechtspraak is het de taak van de rechter uitspraak te doen over een of meer vorderingen uitgaande van een of meer partijen. Een vordering is de concrete uitoefening van een rechtsvordering, hetzij de inleidende, hetzij een tussenvordering. De rechtsvordering zelf kan men omschrijven als het recht een beroep doen op een rechter om een subjectief recht te doen gelden of handhaven. ${ }^{7}$

Traditioneel onderscheidde men - en onderscheid ik in dit preadvies - bij een vordering de volgende bestanddelen:

- de oorzaak of het juridisch relevant feitelijk gegeven (gebeurtenis, handeling, houding of toestand) dat tot het geschil aanleiding heeft gegeven en de aan de vordering ten grondslag ligt. ${ }^{8}$

- het voorwerp van de vordering, d.i. datgene waartoe de vordering strekt, wat van de tegenpartij wordt gevorderd en waartoe de rechter wordt gevraagd haar te veroordelen, ${ }^{9}$

4 S. JOHNSON, 'Cowley' in The Lives of the Most Eminent English Poets, with Critical Observations on Their Works, Londen, C. Bathurst, J. Buckland, W. Strahan et al., I779, s.p.

5 Voor de definities van de Belgische juridische termen heb ik gebruik gemaakt van E. DIRIX, B. TILLEMAN en P. VAN ORSHOVEN (red.), De Valks Juridisch Woordenboek, Antwerpen, Intersentia, 20I0, 62I p. In deze tekst verwijs ik daarnaar als DIRIX, met opgave van het trefwoord. Voor algemene termen heb ik mij verlaten op Van Dale Groot Woordenboek der Nederlandse Taal, in zijn onlineversie Dikke Van Dale genoemd, www.vandale.nl. Dat is mijn bron als ik het in de tekst heb over 'het woordenboek'.

6 S. JOHNSON, Preface van de A Dictionary of the English Language in which the Words are Deduced from their Originals, and Illustrated in Their Different Significations by Examples from the best Writers to which are Prefixed, a History of the Language and an English Grammar, Londen, J. and P. Knapton, T. and T. Longman, C. Hitch and L. Hawes, R. Millar and R. and J. Dodslesy, I755.

7 DIRIX, twn. vordering en rechtsvordering.

8 Vgl. DIRIX, tw. vordering. Ook een overeenkomst heeft een oorzaak en de term heeft er dezelfde connotatie als bij een vordering: het is de doorslaggevende reden waarom iemand zich tot iets verbonden heeft; zie DIRIX, tw. oorzaak. Zoals verder nog zal blijken, heeft het Hof van Cassatie de term oorzaak van een vordering nagenoeg verlaten, het begrip echter niet: zie nr. 47 .

9 DIRIX, tw. vordering. Ook deze term wordt in dezelfde zin gebruikt m.b.t. overeenkomsten: het voorwerp is het concrete rechtsgevolg dat partijen beogen bij het sluiten van een overeenkomst; zie DIRIX, tw. voorwerp. 
- de rechtsgrond van de vordering, ${ }^{\text {Io }}$ d.i. de juridische, doorgaans materieelrechtelijke grondslag van een vordering in rechte, de rechtsregel waaraan de vordering wordt getoetst en waarvan de toepassing tot het beoogde rechtsgevolg leidt, zodat de eisende partij doorgaans de schending daarvan inroept.

Om aan te duiden wat de partijen en de rechter doen m.b.t. een vordering, bestaan verschillende termen. Ze op één hoop gooien, kan natuurlijk en is vandaag zelfs 'in de mode', maar het geeft blijk van weinig verfijning.

Een partij die een vordering instelt, ${ }^{\mathrm{II}}$ vermeldt daarbij noodzakelijkerwijze een of meer juridisch relevante feitelijke gegevens, d.i. gebeurtenissen, handelingen, houdingen of toestanden, m.a.w. wat men de oorzaak van haar vordering pleegde te noemen en wat ik in dit preadvies nog altijd zo noem. Het meest geëigende werkwoord hiervoor is aanvoeren, door het woordenboek omschreven als 'met zeker oogmerk vermelden, te pas brengen'. 'Aanvoeren' is m.a.w. iets gericht naar voren schuiven. ${ }^{12}$ Op het belang van dit gericht zijn kom ik nog terug. ${ }^{13}$

Het voorwerp van een vordering wordt uiteraard het best aangeduid als het lijdend voorwerp van een zin met vragen, eisen of vorderen: de eisende partij claimt iets.

De rechtsgrond ten slotte wordt ingeroepen ${ }^{14}$ of opgeworpen. ${ }^{15}$ Men kan zich ook op een rechtsgrond beroepen. Dat gebeurt in het middel of de middelen.

Kunnen dezelfde termen worden gebruikt bij een tegenvordering van de verwerende partij, bij louter verweer klinken ze op het eerste gezicht iets vreemder. De oorzaak van het verweer zal in veel gevallen dezelfde zijn als die van de vordering van de eiser. Maar de verweerder kan natuurlijk andere gebeurtenissen, handelingen, houdingen en toestanden aanvoeren. Zoals een vordering, heeft een verweer een voorwerp (de verwerende partij vordert de onontvankelijkverklaring, de ongegrondverklaring en afwijzing van de vordering van de eiser, de reductie van het gevorderde

Ik verkies die term boven het soms ook gebruikte woord onderwerp van de vordering omdat dit laatste verwarring kan opwekken met het voorwerp van de vordering: in het Frans worden beide vertaald als 'objet de la demande'. Het Duits maakt nog beter een onderscheid dan het Nederlandse onderwerp en voorwerp door respectievelijk te spreken van Anspruchsgrundlage en Gegenstand. Zie voor dit alles DIRIX, tw. vordering.

II Een eis wordt gesteld, een vordering ingesteld.

I2 Dat doelgerichte is altijd in het woord aanwezig geweest, zo blijkt uit het Woordenboek der Nederlandsche Taal: aan staat er 'in den zin van bereiking van eene plaats' (WNT, te raadplegen via http://gtb.inl.nl/).

I3 Zie nr. 42.

I4 Inroepen is volgens het woordenboek Belgisch-Nederlands voor... aanvoeren. Maar als men aanvoeren ook gebruikt m.bt. de rechtsgrond, $\mathrm{nl}$. in de betekenis van 'ter staving van hetgeen beweerd wordt, te berde brengen', hanteert men voor het juridisch bestanddeel van de vordering dezelfde term als om 'met een zeker oogmerk vermelden, te pas brengen' aan te duiden, m.a.w. voor wat de eisende partij doet m.b.t. de oorzaak, het feitelijke bestanddeel van haar vordering. Het NederlandsNederlands is dus minder genuanceerd, zodat ik de voorkeur geef aan het Belgisch-Nederlandse inroepen als het om een rechtsgrond gaat.

I5 Het woordenboek geeft bij het trefwoord exceptie het voorbeeld van een exceptie opwerpen. 
bedrag, veroordeling van de eiser tot de kosten enz.) en een rechtsgrond (de regels voor de ontvankelijkheid van vorderingen, de andere uitlegging die moet worden gegeven aan de bepaling die de eiser inroept, de bepaling die de eisende partij het recht ontzegt waarop haar vordering steunt, de regel dat een schadelijder van de schadeverwekker geen vergoeding kan krijgen die groter is dan de geleden schade enz.). Alles wat hieronder wordt gezegd m.b.t. de vordering geldt m.a.w. ook voor het verweer.

\section{Hoofdstuk I. Algemene beschouwingen over de taak van de rechter en de rolverdeling tussen rechter en partijen in het proces}

\section{I.I Inleiding}

5. Na de publicatie van de tekst die Krings en Deconinck in I982 als Belgisch preadvies uitbrachten voor de Vereniging voor de vergelijkende studie van het recht van België en Nederland ${ }^{16}$ zijn in België, zoals in Nederland, ${ }^{17}$ heel wat artikelen gepubliceerd over de taak van de rechter in het algemeen, de ambtshalve aanvulling van rechtsgronden in het bijzonder en dit zowel in het Nederlands ${ }^{18}$ als in het Frans. ${ }^{19}$ Ook in boeken kwam het onderwerp nog prominent aan bod. ${ }^{20}$

I6 E. KRINGS en B. DECONINCK, 'Het ambtshalve aanvullen van rechtsgronden', TPR I982, 655-682.

I7 ASSER, voetnoot I.

I8 P. LEMMENS, 'De ambtshalve aanvulling van rechtsgronden en de eerbiediging van de rechten van de verdediging', RW I982-83, 2I88-2I9I; T. TANGHE, 'De rechter kan een overeenkomst niet ambtshalve vernietigen', TBBR 20I3, afl. 5, 236-240; J. VAN DONINCK, 'Ambtshalve aanvulling van rechtsgronden: een tour d'horizon' in M. PIERS, H. STORME en J. VERHELLEN (eds.), Liber Amicorum Johan Erauw, Antwerpen, 20I4, Intersentia, 229-24; A. VANDERHAEGHEN, 'Bepalen van de oorzaak van de vordering' (noot onder Gent ro april 2008), NJW 2009, afl. 200, 327-328; J. VAN DONINCK, 'Grenzen aan de taak van de rechter als hoeder van het algemeen belang' (noot onder Cass. 28 september 20I2), RW 20I2-I3, afl. 23, 897-899; C. VAN SEVEREN, 'Beschikkingsbeginsel vs. taak van de rechter' (noot onder Antwerpen 20 januari 20I4), NjW 20I5, 20.

I9 B. BIEMAR, H. BOULARBAH, F. LAUNE, C. MARQUET, «L'instruction de la cause et les incidents» in Actualités en droit judiciaire, Larcier, Brussel, 2013, 442 p.; C. GINESTET, «Les notions d'objet et de cause» in Procédure civile et procédure pénale. Unité ou diversité ?, Brussel, Bruylant, 20I4, 338 p.; C. MARQUET, «Les défenses en droit judiciaire: vers un ordre public procédural» in H. BOULARBAH en J.F. VAN DROOGHENBROECK, Les défenses en droit judiciaire privé, Brussel, Larcier, 20Io, 272 p.; D. MOUGENOT, «Actualités en matière d'office du juge - Quelques réflexions d'un magistrat», RRD 2009, afl. I30-I3I, 26-34; L. SIMONT, P. FORIERS, "Office du juge et moyen nouveau dans la jurisprudence récente» in B. DAUWE, B. DE GRYSE, E. DE GRYSE, B. MAES, en K. VAN LINT (eds.), Liber Amicorum Ludovic De Gryse, Gent, Larcier, 20I2, 706 p.; Y. STRICKLER, «Les notions d'objet et de cause» in S. AMRANI MEKKI (ed.) in Procédure civile et procédure pénale. Unité ou diversité ?, Brussel, Bruylant, 20I4, 338 p.; C. TUBEUF, «L'accord procédural en droit international privé et l'office du juge au cours d'une procédure judiciaire», TBBR 2003, afl. 4, 226-235; J.F. VAN DROOGHENBROECK, "Chronique de l'office du juge», JLMB 20I3, afl. 25, I307-I320; J.F. VAN DROOGHENBROECK, "[Procès équitable] Faire l'économie de la contradiction?", RCJB 20I3, afl. 2, 203-248; J.F. VAN DROOGHENBROECK, «Une parfaite définition de l'office du juge» (noot onder Cass. 2 april 20I0), JLMB 20I0, afl. 26, I239-I242; J. F. VAN DROOGHENBROECK, «La requalification judiciaire du contrat et des prétentions qui en découlent» in P. WERY en S. STIJNS (eds.), De rol van de rechter in het contract, Brugge, Die Keure, 20I4, $643 \mathrm{p}$.

20 Bij uitstek in het doctoraal proefschrift van B. ALLEMEERSCH, Taakverdeling in het burgerlijk proces, Antwerpen, Intersentia, 2007, 67I p. 
Is 34 jaar later een herbespreking van het onderwerp van Nederlandse kant aangewezen omwille van wettelijke ingrepen, in België is het recente rechtspraak van het Hof van Cassatie die tot een andere kijk heeft geleid. Het Hof heeft de formulering van wat volgens hem de taak van de rechter is, in opeenvolgende arresten, gespreid over een periode van tien jaar, verfijnd.

De start is terug te vinden in een arrest van I4 april 2005, ${ }^{21}$ waarin het Hof overweegt dat 'de rechter gehouden is het geschil te beslechten overeenkomstig de daarop toepasselijke rechtsregel; dat hij, mits hij het recht van verdediging eerbiedigt, de plicht heeft ambtshalve de rechtsmiddelen op te werpen waarvan de toepassing geboden is door de feiten, die door de partijen in het bijzonder worden aangevoerd tot staving van hun eisen'. ${ }^{22}$ Het is vooral de eerste zin die vernieuwend was. ${ }^{23}$

\section{In latere arresten zijn andere formuleringen opdoken.}

De onvolprezen kampioen onder de publicisten over het onderwerp is Van Drooghenbroeck. Als iemand als hij van oordeel is dat de formulering van een Franstalig cassatiearrest van 2 april 20I0, die vrij, maar toch niet volledig getrouw wordt weergegeven in de Nederlandse vertaling van dat arrest, te verkiezen is boven alle andere, ${ }^{24}$ dan ben ik geneigd dat deemoedig te aanvaarden. In het Nederlands luidt die best choice als volgt: 'De rechter is gehouden de juridische aard te onderzoeken van de hem door de partijen voorgelegde eisen en kan, ongeacht de juridische omschrijuing die de partijen daaraan hebben gegeven, ambtshalve de aangevoerde redenen aanvullen, mits hij geen betwisting opwerpt waarvan de partijen het bestaan hebben uitgesloten, dat hij enkel steunt op regelmatig aan zijn oordeel voorgelegde feiten en het voorwerp van de vordering niet wijzigt. Daarenboven moet hij, met eerbiediging van het recht van verdediging, ambtshalve de rechtsmiddelen opwerpen waarvan de toepassing vereist wordt door de feiten die de partijen met name tot staving van hun eisen hebben aangevoerd'. 25

Toch is er nadien nog een formulering gekomen die nog beter is omdat zij vollediger en preciezer is, $\mathrm{nl}$. die van een oorspronkelijk Nederlandstalig arrest van I4 december 2012: 'De rechter is gehouden het geschil te beslechten overeenkomstig de

2I Een paar jaar later dus dan de Nederlandse wetswijzigingen. Niettemin was (ook) in dezen niet Nederland het gidsland, maar Frankrijk (vergelijk de 'taakformule' van het Belgische Hof van Cassatie met de artikelen 6 - 8 en I2 - I3 van de Code de procédure civile).

22 De tweede zin kwam al voor in de "formule» gebruikt. Zie bv. kort voordien nog Cass. 9 mei 2003, C.00.0203.N: 'De rechter moet de juridische aard van de door de partijen aangevoerde feiten onderzoeken en kan, ongeacht de omschrijving die zij daaraan hebben gegeven, de voor hem aangevoerde redenen ambtshalve aanvullen op voorwaarde dat hij geen betwisting opwerpt waarvan partijen het bestaan hebben uitgesloten, dat hij enkel steunt op feiten die hem regelmatig ter beoordeling zijn overgelegd en dat hij noch het voorwerp noch de oorzaak van de vordering wijzigt'.

23 In het Frans staat er in de laatste zin 'spécialement invoqués', in de Nederlandse vertaling 'aangevoerd' zonder meer. Zie echter nr. 49 en voetnoot $\mathrm{I} 2$ in dit preadvies.

24 J.F. VAN DROOGHENBROECK, «Une parfaite définition de l'office du juge» (noot onder Cass. 2 april 2010), JLMB 2010, afl. 26, I239-I242.

25 Cass. 2 april 2010, C.09.0204.F. Als bij een verwijzing naar een cassatiearrest enkel het rolnummer van de zaak en geen vindplaats staat, is het arrest te vinden in de databank Juridat http://jure.juridat. just.fgov.be/JuridatSearchCombined/?lang=nl\&jur=I. 
daarop van toepassing zijnde rechtsregels. Hij moet de juridische aard van de door de partijen aangevoerde feiten en handelingen onderzoeken, en mag, ongeacht de juridische omschrijving die de partijen daaraan hebben gegeven, de door hen aangevoerde redenen ambtshalve aanvullen op voorwaarde dat hij geen betwisting opwerpt waarvan de partijen bij conclusie het bestaan hebben uitgesloten, dat hij enkel steunt op elementen die hem regelmatig zijn voorgelegd, dat hij het voorwerp van de vordering niet wijzigt en dat hij daarbij het recht van verdediging van partijen niet miskent. Hij heeft de plicht ambtshalve de rechtsmiddelen op te werpen waarvan de toepassing geboden is door de feiten die door de partijen in het bijzonder worden aangevoerd tot staving van hun eisen. Dit houdt niet in dat de rechter gehouden is alle in het licht van de vaststaande feiten van het geschil mogelijke, doch nietaangevoerde rechtsgronden op hun toepasselijkheid te onderzoeken, doch enkel dat hij, mits eerbiediging van het recht van verdediging, de toepasselijkheid dient te onderzoeken van de niet aangevoerde rechtsgronden die zich door de feiten zoals zij in het bijzonder worden aangevoerd, onmiskenbaar aan hem opdringen'. ${ }^{26}$ Het is die formulering die ik aanhoud als 'de taakformule' van het Hof van Cassatie en die ik aan het einde van dit preadvies zelf nog eens aanvul.

6. De in het preadvies-Asser geschetste achtergronden die aan de basis liggen van de evolutie die te onderkennen is in de formulering van die taak van de rechter, hebben ongetwijfeld ook in België gespeeld. Lijdelijkheid is een eigenschap die in de huidige maatschappij niet hoog meer wordt aangeslagen, zeker niet als men daaraan een verkeerde invulling geeft en die, evenzeer ten onrechte, op rechters toepast.

Evenmin als de Nederlandse, bevat de Belgische Grondwet een bepaling die het recht op toegang tot de rechter en het recht op een eerlijk proces vooropstellen, zodat artikel 6 van het EVRM ook in België de referentiebepaling is.

\section{I.2 Een eerlijk proces}

7. Gelet op wat voorafgaat, wekt het geen verbazing dat de invulling van het recht op een eerlijk proces in België op dezelfde wijze gebeurt als in Nederland. Maar, zoals al gezegd, in België staat de wetgever niet in voor de invulling van alle facetten van dat fundamenteel grondrecht.

Asser heeft het in zijn Nederlandse preadvies over vijf waarborgen: het beginsel van de tegenspraak, de wapengelijkheid, het recht op een onpartijdige rechter, de motiveringsverplichting en de verplichting van de rechter uitspraak te doen op basis van de werkelijke feiten. ${ }^{27}$

26 Cass. I4 december 20I2, C.I2.00I8.N. De Franse vertaling luidt: 'Le juge est tenu de trancher le litige conformément aux règles de droit qui y sont applicables. Il est tenu d'examiner la nature juridique des faits et actes invoqués par les parties et peut, quelle que soit la qualification juridique que celles-ci leur ont donnée, suppléer d'office aux motifs invoqués dès lors qu'il n'élève aucune contestation dont les parties ont exclu l'existence dans leurs conclusions, qu'il se fonde uniquement sur des faits régulièrement soumis à son appréciation, qu'il ne modifie pas l'objet de la demande et qu'il respecte les droits de la défense. Il est tenu de soulever d'office les moyens de droit dont l'application est requise par les faits spécialement invoqués par les parties à l'appui de leurs demandes'.

27 ASSER, onder I.2, tweede alinea. 
In België werden vrij recent de volgende zes principes opgesomd als de beginselen die het eerlijk proces kenmerken: (I) toegang tot een rechterlijke instantie, (2) onafhankelijkheid en onpartijdigheid, (3) recht van verdediging en eerlijke behandeling van de zaak, (4) behandeling binnen een redelijke termijn, (5) openbare behandeling en openbare uitspraak en (6) motivering van de uitspraak. ${ }^{28}$

Zijn de eerste vier waarborgen waarvan Asser gewaagt, zonder moeite terug te vinden in de Belgische wetgeving en rechtspraak, ${ }^{29}$ een duidelijke verplichting uitspraak te doen op basis van de werkelijke feiten komt in België niet naar voren. De rechtsleer pleit weliswaar meer en meer een waarheidsplicht in het burgerlijk proces, op grond van de vereiste procesloyauteit, in die zin dat de partijen niet wetens en willens leugenachtige beweringen mogen doen, ${ }^{30}$ maar de wettelijke aanknopingspunten daarvoor zijn schaars. In het Belgisch recht lijkt inderdaad een hoger belang te worden gehecht aan de conflict oplossende waarde van een rechterlijke uitspraak dan aan haar waarheidsgehalte. ${ }^{3 \mathrm{I}}$ Belgen zijn m.a.w. pragmatischer, wat al langer geweten is. Die benadering komt onder meer tot uiting in het bewijsrecht, dat niet als hoofddoelstelling heeft de objectieve waarheid bloot te leggen, maar wel te vermijden dat geschillen eindeloos aanslepen doordat de partijen blijven twisten, niet alleen over hun conflict ten gronde, maar ook over het door hen aangewende bewijsmateriaal. De objectieve waarheid wordt daarbij in zekere mate opgeofferd aan de juridische waarheid, met het oog op rechtszekerheid. ${ }^{32}$ Ook het beschikkingsbeginsel, dat uiteraard verder nog aan bod komt in dit preadvies, ${ }^{33}$ kan de zoektocht naar de objectieve waarheid in de weg staan. ${ }^{34}$ Zo oordeelde het Hof van Cassatie dat wanneer de partijen de toepassing van artikel 877 van het Gerechtelijk Wetboek in een procedureakkoord uitdrukkelijk hebben uitgesloten, de rechter het beschikkingsbeginsel schendt wanneer hij niettemin die bepaling toepast en aldus een partij of een derde beveelt het stuk over te leggen dat het bewijs inhoudt van een ter zake dienend feit en waarvan vermoed wordt dat hij het onder zich houdt. ${ }^{35}$

28 G. DE BUYZER en L. SCHELLEKENS, 'Stand van zaken en recente ontwikkelingen op het vlak van het eerlijk proces' in P. VAN ORSHOVEN (ed.), Gerechtelijk recht, reeks Themis, Brugge, Die Keure 20IO, I-34.

29 Zoals ook de drie beginselen van de 'Belgische invulling' die niet aan bod komen in de opsomming van Asser, niettemin ook in Nederland gelden.

30 B. ALLEMEERSCH, Taakverdeling in het burgerlijk proces, Antwerpen, Intersentia, 2007, p. 368, nr. 55 e.v.; B. SAMYN, Privaatrechtelijk bewijs, Gent, Story Publishers, 2012, p. 95, nr. 75.

3I Die benadering is mogelijk beïnvloed door het feit dat men in het 'katholieke' België heel goed weet dat ook al vragen rechters om de waarheid, zij die niet kunnen achterhalen: zelfs Jezus gaf geen antwoord op de vraag naar de waarheid van Pontius Pilatus (Johannes, I8, 38 - in de Statenbijbelvertaling: 'Pilatus zeide tot Hem: Wat is waarheid? En als hij dat gezegd had, ging hij wederom uit tot de Joden, en zeide tot hen: Ik vind geen schuld in Hem'; Pilatus was een rechter: 'Als Pilatus dan dit woord hoorde, bracht hij Jezus uit, en zat neder op den rechterstoel, in de plaats, genaamd Lithostrotos, en in het Hebreeuws Gabbatha' (idem, ibidem, vers I3).

32 B. CATTOIR, Burgerlijk bewijsrecht in APR, Mechelen, Kluwer, 20I3, nr. 6o.

33 Zie nr. I8.

34 Al bestaat betwisting over de vraag of de partijen wel de rechterlijke bevoegdheid m.b.t. onderzoeksmaatregelen mogen uitsluiten of moduleren: B. SAMYN, Privaatrechtelijk bewijs, Gent, Story Publishers, 2012, 446.

35 Cass. 2 juni 2005, C.04.0099.F. 


\section{I.3 De actieve rechter}

8. De uitdrukking actieve rechter die Asser gebruikt, komt ook in België voor. Tot het al genoemde arrest van het Hof van Cassatie van 14 april $2005^{36}$ gebruikte men die vooral, zij het niet uitsluitend, als het ging om het rechterlijk optreden ten aanzien van proces vertragende handelingen, houdingen of manoeuvres. ${ }^{37}$ Maar sinds 2005 heeft het begrip een veel ruimere inhoud gekregen, die, zoals het geval is in Nederland en zoals vermeld door Asser, het gevolg is van gewijzigde maatschappelijke opvattingen. Ik licht hieronder toe hoe ik dat zie.

\section{I.4 Partijautonomie en lijdelijkheid}

9. Na veertig jaar advocatuur ben ik diep in mijzelf altijd een voorstander gebleven van wat men de lijdelijke rol van de rechter pleegt te noemen. Als advocaat verwacht ik van een rechter dat hij goed luistert, nadenkt en gemotiveerd beslist, bij voorkeur in de door mij gewenste zin. Tussenkomen in het debat of zelf met de partijen in debat gaan, hoeft de rechter voor mij in de regel niet. $3^{8}$ Als hij iets te zeggen heeft, dat hij het dan in zijn vonnis zegt, zoals een advocaat wat hij te zeggen heeft, op papier zet in zijn conclusies en mondeling toelicht in zijn pleidooi. Commentaar hoeft in beginsel van geen van beide kanten. Maar ik besef en aanvaard (wat kan ik anders?) dat die zienswijze ouderwets en achterhaald is. Daarvoor zijn verschillende redenen aan te halen.

Allemeersch wijst in zijn doctoraal proefschrift op de nieuwe maatschappelijke realiteit: een emancipatie van de burger waardoor de evidentie van het overheidsoptreden wordt in vraag gesteld. De klassieke gezagsverhouding, die ook speelt in de relatie tussen de rechter enerzijds, anderzijds de advocaten en de partijen, moet wijken voor een relatie van samenwerking en overleg. De rechter wordt om een interventie gevraagd, niet louter om een juridisch oordeel te vellen, maar even vaak om een oplossing uit te werken voor een probleem dat niet enkel met rechten, maar ook en soms vooral met belangen te maken heeft. De verwachtingen ten aanzien van de rechter zijn dus gestegen. Daarnaast wijst Allemeersch op de herwaardering van het beroep van magistraat sinds de oprichting van de Hoge Raad voor de Justitie en op de economisering en de socialisering van het procesdenken. ${ }^{39}$ De rechter is belast met een openbare dienst en de performantie daarvan, waarop de burger recht heeft, vergt dat hij zich in de uitoefening van zijn ambt niet afstandelijk en passief opstelt.

Die nieuwe benadering is al veel vroeger naar voren gekomen in bestuurlijke aangelegenheden. Ik geef een voorbeeld uit het socialezekerheidsrecht. Tot in een in mijn ogen nog vrij recent verleden stelden ambtenaren en werknemers van instellingen

36 Zie nr. 5 .

37 Zie bv. P. ADRIAENSEN, 'De actieve rechter in het hof van beroep te Antwerpen' in Gerechtelijke achterstand: geen noodzakelijk kwaad., Brussel, Bruylant, 2004, 265-285; E. BREWAEYS, 'Actieve rechter en de procedure' in F. MOEYKENS (ed.), De Praktijkjurist VIII, Gent, Academia Press, 2004, 179-204.

38 In dat opzicht is het Hof van Cassatie voor mij de ideale rechter.

39 B. ALLEMEERSCH, Taakverdeling in het burgerlijk proces, Antwerpen, Intersentia, 2007, 6r e.v. en 590. 
van sociale zekerheid zich doorgaans nogal passief op ten aanzien van de burger, de sociaal verzekerde, die zich tot hen richtte. Met het oog op besparingen werden zij daartoe soms zelfs aangemoedigd door de overheid. Terwijl de instellingen van sociale zekerheid aldus bijvoorbeeld een aanvraag die niet voor hen bestemd was, zonder meer in de prullenbak konden gooien, zij de burger bedienden wanneer het hen eens paste, van hen niet verwacht werd dat zij de sociaal verzekerde uitleg gaven over de stappen die hij moest zetten om het gewenste gevolg te verkrijgen, zij zich mochten hullen in 'ambtenarees', de burger in het ongewisse mochten laten omtrent wat hem te doen stond als hij met een beslissing niet akkoord ging enzovoorts, verwacht men nu van wie de dienst uitmaakt, dat hij de burger die zich tot hem wendt, binnen een redelijke termijn alle mogelijke inlichtingen en zelfs raad geeft over zijn rechten en verplichtingen, dat hij een vraag die verkeerdelijk aan hem is gericht, doorstuurt naar de bevoegde dienst en de burger daarvan op de hoogte brengt, dat hij zich uitdrukt in een voor het publiek bevattelijke taal, dat hij de sociaal verzekerde die een voor hem ongunstige beslissing krijgt, informeert over de verhaalsmogelijkheden, -vormen en -termijnen, enzovoorts. En niet alleen verwacht de maatschappij dat, de overheid legt het ook op..$^{40}$

Tussen de genoemde verwachtingen en verplichtingen is er één die bestaat in ambtshalve optreden en dus nauw verwant is met het onderwerp van dit preadvies: wanneer het gaat om sociale grondrechten, zoals het recht op sociale zekerheid, moeten openbare en particuliere diensten, als zij dat kunnen, optreden zonder dat hen daarom werd verzocht. De burger moet altijd zoveel mogelijk krijgen waarop hij recht heeft, ook al doet hij daarvoor niet de wenselijke of de juiste demarches. ${ }^{4 \mathrm{I}}$ Stelt een instelling van sociale zekerheid een materiële of juridische vergissing vast, dan moet zij op eigen initiatief een nieuwe beslissing nemen, zelfs al is die nadelig voor de financiën van de instelling of van de sociale zekerheid..$^{42}$

Waarom zou wat geldt in het domein van de sociale zekerheid niet mutatis mutandis ook gelden voor de openbare dienst die rechtsbedeling heet? Terecht herinnert Asser in zijn preadvies ernaar dat rechtsbescherming een sociaal grondrecht is. ${ }^{43}$

Io. Ten slotte wil ik de aandacht vestigen op nog een parallel tussen het actief optreden van de rechter en dat van instellingen van sociale zekerheid. In de Belgische sociale zekerheid moest (en moet) de sociaal verzekerde zich in veel gevallen sterk verlaten op de tussenschakels tussen de overheid (de verschillende rijksdiensten, rijksinstituten en fondsen voor sociale zekerheid) en hemzelf, op de zgn.

40 De genoemde verwachtingen zijn de verplichtingen die de artikelen 3 e.v. van de Wet Handvest Sociaal Verzekerde (de wet van II april 1995 tot invoering van het 'handvest' van de sociaal verzekerde) oplegt aan alle publieke en particuliere instellingen van sociale zekerheid. Men zou ook kunnen denken aan de in dezelfde richting geëvolueerde verhoudingen tussen docenten en studenten in het onderwijs. dat materieel mogelijk is, ambtshalve worden toegekend.

42 Art. I7 Wet Handvest Sociaal Verzekerde.

43 ASSER, onder I.I. 
meewerkende instellingen (kinderbijslagfondsen, ziekenfondsen, werkloosheidskassen van de vakbonden, socialeverzekeringskassen voor zelfstandigen enz.). Aanvankelijk waren zij de enigen die de sociaal verzekerden hielpen met informatie, raad en bijstand. De burgers waren dan ook vaak van die instellingen afhankelijk. De Wet Handvest Sociaal Verzekerde heeft het belang van die tussenschakels gereduceerd door, zoals hierboven al gezegd, iedere instelling voor sociale zekerheid op te leggen niet alleen te antwoorden en te reageren op vragen of aanvragen van de sociaal verzekerden, maar ook hun uit eigen beweging alle bijkomende informatie te geven die nodig is voor de behandeling van hun verzoek of het behoud van hun rechten en hun zelfs raad te geven over hun rechten en verplichtingen, dus zelfs zonder tussenkomst van de gebruikelijke tussenpersonen of ingaande tegen het standpunt of de houding van deze laatsten. Het recht op sociale zekerheid realiseren met een zo nodig zelfs ambtshalve genomen beslissing, dat staat als doelstelling voorop.

Het actievere optreden van de rechter en de impact die dat heeft op het optreden en de rol van de advocaten, kadert naar mijn oordeel ook in die maatschappelijke evolutie. Als een partij in persoon optreedt, staat zij in de regel juridisch zwak; als zij vertegenwoordigd wordt door een advocaat, is zij doorgaans in grote mate afhankelijk van diens optreden. Als de rechter zijn rol beperkt tot luisteren en beslissen, kan een partij daarvan het slachtoffer zijn. Dat wordt niet meer aanvaard en het hoort ook niet: ius omnibus civibus scriptum, ook voor de burgers die niet of slecht worden bijgestaan. Een maatschappij kan en mag niet dulden dat geen recht geschiedt wanneer de rechter, wiens taak het is recht te speken, dat kan voorkomen of vermijden door een proactief optreden.

Ook in deze context kan men dan spreken van toenemende aandacht voor het effectiviteitsbeginsel. ${ }^{44}$ het recht mag niet worden gereduceerd tot fictie door procesrechtelijke passiviteit van de rechter.

II. Maar het activisme van de rechter mag ook niet worden overdreven. ${ }^{45}$ In zijn extreme vorm leidt het tot het volgende scenario: elke partij zegt waarover het geschil gaat (en maakt aldus de oorzaak van de vordering duidelijk) en wat zij wenst dat er gebeurt (formuleert dus het voorwerp van de vordering als eiser of vraagt, als verweerder, de afwijzing daarvan), waarna de rechter de gepaste vragen stelt, de aangewezen onderzoeksmaatregelen beveelt en nadien een beslissing neemt op de juiste rechtsgrond. Dat dergelijke inquisitoire opstelling van de civiele rechter het beroep van advocaat overbodig zou maken, is een ernstig bezwaar, althans voor advocaten, maar niet het grootste. Een rechterlijke uitspraak maakt meer kans de juridische en wellicht ook de werkelijke waarheid te benaderen wanneer hij het resultaat is van een dialectisch proces dat met de gepaste middelen wordt gevoerd.

44 Zie over dat begrip in Europeesrechtelijke context A.G.F. ANCERY, Ambtshalve toepassing van EU-recht, Deventer, Kluwer, 20I2, p. I03 e.v.

45 In België heeft dat woord overigens een bijzondere betekenis. Zie over dat onderwerp het recent verschenen boek van Lode WILS, Onverfranst, onverduitst. Flamenpolitik, activisme, frontbeweging, Kalmthout, Pelckmans, 20I4, 347 p. 
Anders dan het geval is bij echte wetenschappen, is in het recht (bijna) elke stelling falsifieerbaar. En falsificatie, die men een 'verwetenschappelijkte' vorm van tegenspraak zou kunnen noemen, draagt bij tot waarheidsvorming.

Het is dan ook een goede zaak dat, zoals opgemerkt door Allemeersch, parallel met de activering van de rechter een evolutie loopt die steeds meer de nadruk legt op de eigen verantwoordelijkheid van de partijen voor een goede procesorde, waarbij de van hen verwachte procesloyauteit niet beperkt blijft tot een verplichting van eerlijkheid, maar ook inzet omvat, wat hij 'partijwerkzaamheid' noemt. ${ }^{6}$

\section{Hoofdstuk 2. Feit en recht}

\section{I Inleiding}

I2. In het beste Belgische boek dat over de verhouding tussen feit en recht is geschreven, zegt de betreurde professor Marc Van Quickenborne: 'De oplossing van het probleem lijkt eenvoudig. Men kan ze bondig en erg euforisch formuleren in het adagium $\mathrm{Da}$ mihi factum; dabo tibi ius. Het blijkt dus aan de partijen toe te komen de feiten aan te brengen, terwijl de rechter op deze feiten de rechtsregel zal toepassen die de inwilliging of de afwijzing van de ingestelde rechtsvordering rechtvaardigt'. ${ }^{47}$ Het is de taak van de rechter 'recht' te spreken, d.w.z. te onderzoeken of het positum, de feiten, het petitum, het gevorderde, rechtvaardigt.

Het voornoemde adagium is niet met zoveel woorden erkend als algemeen rechtsbeginsel. Het is het beschikkingsbeginsel dat in de rechtspraak van het Hof van Cassatie de taakverdeling tussen rechter en partijen beheerst. Niettemin geeft 'da mihi factum, dabo tibi ius' aan dat die taakverdeling vooral verloopt langs de as feiten- recht. Zo is het aanvoeren van de feiten in het burgerlijk proces het monopolie van de partijen. De rechter mag in beginsel zelf geen feiten aanbrengen die hem niet door de partijen zijn gesignaleerd. $4^{8}$ Maar hij mag wel autonoom het recht toepassen. De moeilijkheid zit evenwel in het bepalen van de draagwijdte van die rechterlijke opdracht en meer bepaald in de vraag wanneer en onder welke voorwaarden de rechter de door de partijen naar voren gebrachte rechtsgronden terzijde mag schuiven en vervangen door andere of met andere mag aanvullen en in welke mate hij die beslissing mede kan steunen op feiten die de partijen niet speciaal, in het bijzonder, hebben aangevoerd met het oog op het slagen van hun vordering of verweer.

46 B. ALLEMEERSCH, Taakverdeling in het burgerlijk proces, Antwerpen, Intersentia, 2007, 598.

47 M. VAN QUICKENBORNE, Feit en recht of de rechter en de procespartijen, Brussel, H. Swinnen, I987, I55 p.

48 De rechter mag wel rekening houden met algemeen bekende feiten (o.m. Cass. I6 december I98I, Arr. Cass. I98I-82, 53I; Cass. 24 januari 1995, Rec. Cass. I995, 283, noot P. TRAEST), maar geen uitspraak doen op grond van zijn persoonlijke kennis van de feiten die hij niet heeft vernomen in de loop van het proces (Cass. 6 januari I982, Arr. Cass. I98I-82, 578). 
Wanneer de partijen zich ertoe beperken blote, niet-gekwalificeerde feiten aan te brengen ${ }^{49}$ en zich niet uitlaten over de juridische kant van de zaak, heeft de rechter de vrijheid naar eigen inzicht de toepasselijke rechtsregels aan te wijzen. ${ }^{\circ}$ De hierboven beschreven taakverdeling op het vlak van de feiten en het recht speelt dan ten volle.

Die situatie is echter uiteraard zeldzaam. Meestal bevat een door de rechter ambtshalve opgeworpen middel zowel feiten als recht. Zo zal het voor de rechter die de door de partijen naar voren geschoven rechtsgrond wil vervangen door een andere, vaak niet mogelijk zijn enkel rekening te houden met de feiten die de partijen met het oog op de toepassing van de volgens hen toepasselijke rechtsgrond hebben aangevoerd. Nog minder goed kan men zich voorstellen dat de rechter de vordering of het verweer weliswaar aanneemt met toepassing van de door de partijen aangevoerde rechtsregel, maar enkel op grond van feiten die niet uitdrukkelijk door hen zijn aangevoerd in hun conclusies, maar die hij uit het dossier put en die, volgens hem, beter dan de uitdrukkelijk aangevoerde feiten sporen met de door de partijen aangevoerde rechtsregel. In de meeste gevallen zal de rechter dus een middel opwerpen dat 'feiten en recht vermengt' en zal hij, bij de ambtshalve toepassing van een rechtsgrond, ook acht slaan op feiten die in het dossier verscholen zijn, om daaraan een specifieke juridische draagwijdte te geven..$^{51}$

Zoals ook Asser in zijn preadvies opmerkt, is de taakverdeling tussen de partijen en de rechter door de natuurlijke interactie van feiten en recht behoorlijk gecompliceerd..$^{2}$

\subsection{Feiten en rechtsfeiten}

I3. Rechtsfeiten, in de ruime zin van het woord, zijn gebeurtenissen met rechtsgevolgen, 'd.i. zowel feiten of toestanden die intreden of bestaan buiten een specifiek aanwijsbaar menselijk handelen om als menselijke gedragingen waarmee echter het in leven roepen van rechtsgevolgen niet wordt beoogd (zoals een onrechtmatige daad) en rechtshandelingen, d.i. menselijke handelingen, waarmee wel dergelijke gevolgen worden beoogd'. ${ }^{3} \mathrm{Ik}$ denk dat men, iets eenvoudiger, kan spreken van feitelijke gegevens (gebeurtenissen, handelingen, houdingen en toestanden) die op zich of door de context waarin zij zich voordoen, een juridische relevantie hebben, rechtsgevolgen teweegbrengen. Feitelijke of blote feiten hebben en doen dat niet.

Het zijn rechtsfeiten die zijn wat men de 'oorzaak' van het geschil noemt, in die zin dat zij daartoe aanleiding hebben gegeven en aan de vordering ten grondslag liggen. 54

49 Dat kan en mag: G. DE LEVAL, Eléments de la procédure civile, Brussel, De Boeck \& Larcier, $2005,35$.

50 B. ALLEMEERSCH, Taakverdeling in het burgerlijk proces, Antwerpen, Intersentia, 2007, p. I77, nr. 55 ev.

5 I Concl. A. HENKES vóór Cass. 28 mei 2009, Arr.Cass. 2009, afl. 5, I478.

52 ASSER, onder 2.I.

53 DIRIX, tw. rechtsfeit, waar de oorzaak van de vordering wordt omschreven als het rechtsfeit dat het geschil heeft 'uitgelokt', wat het 'oorzakelijk verband' verklaart dat in de term tot uiting komt.

DIRIX, tw. vordering. 
In de praktijk maken de (advocaten van de) partijen niet altijd een duidelijk onderscheid tussen beide. Dat lijkt ook niet nodig. Het behoort tot de taak van de rechter uit te maken welke van de door de partijen naar voren gebrachte feiten moeten worden aangemerkt als feiten waaraan het door hen ingeroepen of het door hem ambtshalve opgeworpen rechtsgevolg is verbonden en welke feiten dus rechtsfeiten zijn. In de processuele context neemt Asser als uitgangspunt aan dat als rechtsfeit geldt, het geheel aan feitelijke informatie die een partij aanvoert ter onderbouwing van het intreden van het door die partij ingeroepen rechtsgevolg, m.a.w. de feitelijke informatie die volgens die partij voldoet aan de kwalificatie die de rechtsregel als voorwaarde stelt om toepasselijk te zijn. ${ }^{55}$ Alle feiten die de partijen in hun procedurestukken vermelden (of zoals ik verder bepleit, die uit door hen overgelegde overtuigingsstukken blijken) ${ }^{56}$ zijn virtueel rechtsfeiten. Uiteindelijk zal de rechter beslissen welke daarvan hij uiteindelijk als zodanig voor zijn beslissing aanhoudt.

De Belgische cassatierechtspraak maakt als het gaat om de taak van de rechter, een onderscheid tussen de feiten die de partijen uitdrukkelijk naar voren brengen tot staving van hun eisen, die zij m.a.w. aanvoeren, en de andere feiten, die zij gewoon vermelden. Dat onderscheid bepaalt met name of de rechter op grond van die feiten al dan niet verplicht is de juridische grondslag van de eis aan te duiden of te kwalificeren, dan wel aan te vullen of te herkwalificeren, m.a.w. of hij moet overgaan tot wat men met een reductie 'ambtshalve aanvulling van de rechtsgronden' pleegt te noemen. ${ }^{57}$ Dat onderscheid, op basis van de wijze waarop de feiten in het proces naar voren zijn gebracht, tussen mogelijkheid en verplichting lijkt in het Nederlandse procesrecht niet te worden gemaakt.

\section{Hoofdstuk 3. De taak van de rechter in het privaatrechtelijk proces}

\section{I Inleiding}

I4. Waar in Nederland vier kernopdrachten van de rechter vervat zijn in drie wetsartikelen, ${ }^{5}$ wordt de opdracht van de rechter in België omschreven in de rechtspraak van het Hof van Cassatie. Het Hof heeft de kern van en de grenzen aan de taak van de rechter in het privaatrechtelijk proces samengevat in een aantal zinnen die ik in dit preadvies gemakshalve de 'taakformule' noem. In die formule komen een aantal voorwaarden en beperkingen voor waarvan sommige ook in andere wetsbepalingen of algemene rechtsbeginselen vervat zijn. Ondanks haar bezwerend overkomend karakter lijkt de formule bovendien maar volledige uitwerking te kunnen hebben als zij wordt aangevuld met bepaalde elementen die daarin onvoldoende tot uiting komen. 59

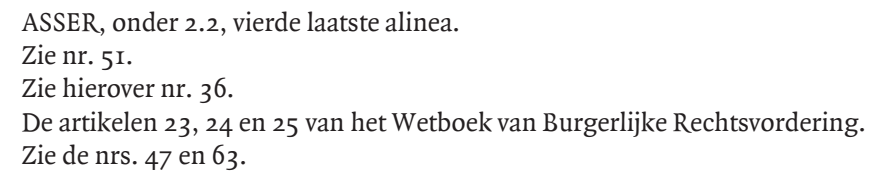


Gemakshalve citeer ik hier nog eens de formule in haar door Van Drooghenbroeck als perfect beschouwde versie. ${ }^{60}$

\begin{abstract}
'De rechter is gehouden de juridische aard te onderzoeken van de hem door de partijen voorgelegde eisen en kan, ongeacht de juridische omschrijuing die de partijen daaraan hebben gegeven, ambtshalve de aangevoerde redenen aanvullen, mits hij geen betwisting opwerpt waarvan de partijen het bestaan hebben uitgesloten, dat hij enkel steunt op regelmatig aan zijn oordeel voorgelegde feiten en het voorwerp van de vordering niet wijzigt. Daarenboven moet hij, met eerbiediging van het recht van verdediging, ambtshalve de rechtsmiddelen opwerpen waarvan de toepassing vereist wordt door de feiten die de partijen met name tot staving van hun eisen hebben aangevoerd.'
\end{abstract}

I5. Zoals de drie bepalingen van het Nederlandse Wetboek van Burgerlijke Rechtsvordering, richt de 'taakformule' van het Belgische Hof van Cassatie zich op gebiedende wijze tot de rechter: 'De rechter is gehouden...' en 'Hij moet...'

Maar, zoals de bedoelde Nederlandse bepalingen, vormt de Belgische 'taakformule' geen keurslijf dat elke soepele invulling of aanvulling belet. Dat is vooreerst al het geval omdat het 'maar' over een jurisprudentiële omschrijving en niet over een wetsbepaling gaat. Bovendien bewijzen de varianten die de formule in de tien jaar van haar bestaan heeft gekend, dat zowel voortschrijdend inzicht als concrete toepassingsgevallen aanpassingen wenselijk of nodig kunnen maken. Laat voorts de wet de partijen, onder bepaalde voorwaarden, toe 'hun' proces te wijzigen door de oorzaak, het voorwerp en de rechtsgrond van de vordering en het verweer aan te passen, ook de rechter moet een zekere beweeglijkheid worden toegestaan. Hij moet daarbij weliswaar op zijn rechterstoel blijven zitten en mag niet over de balie klauteren door de oorzaak of het voorwerp van de vordering of het verweer van een van de partijen te wijzigen. Maar op zijn stoel kan hij, inspelend op de dynamiek (of de ontstentenis daarvan) die van de partijen of hun raadslieden uitgaat, schuifelen, zo niet met de bips, dan toch met de rechtsgronden.

\title{
3.2 Het voorwerp van de vordering (het 'petitum')
}

I6. Wat Asser in zijn preadvies het petitum noemt, noemen wij in België inderdaad, zoals hij vermeldt, gewoon, in deugdelijk Nederlands, het voorwerp van de vordering, 'de zaak waarop iem. of iets een werking uitoefent, waarop de werking gericht is' zegt het woordenboek. Het voorwerp van de vordering is het doel van de processuele actie, de reden waarom een partij zich tot de rechtbank richt, het voordeel dat zij met haar vordering nastreeft, de formulering van haar aanspraak. ${ }^{6 \mathrm{r}}$ Het gaat om een moreel, sociaal of economisch voordeel dat de partijen willen verkrijgen. ${ }^{62}$

60 Zie nr. 5 .

6 I Concl. C. VANDEWAL vóór Cass. 29 mei 2015, C.I3.06I5.N.

$62 \mathrm{~K}$. BROECKX, Het recht op hoger beroep en het beginsel van de dubbele aanleg in het civiele geding, Antwerpen, Maklu, I995, 283; J. VAN COMPERNOLLE en G. CLOSSET-MARCHAL, 'Examen de jurisprudence (I985-I996) Droit judiciaire privé', RCJB I997, 535 . 


\subsubsection{De aard van het voorwerp}

I7. Als voordeel dat een partij met haar vordering nastreeft, is het voorwerp van de vordering in wezen een feitelijke aangelegenheid: de eiser wil een geldsom of wenst een muur afgebroken te zien. Het is met het door de partijen gewenste feitelijk resultaat voor ogen, dat de rechter de rechtsregels moet toepassen. Of de eisende partij een geldsom opeist op basis van extracontractuele dan wel contractuele aansprakelijkheid van de verwerende partij, betreft de rechtsgrond van de vordering, niet het voorwerp ervan. De rechter die een op basis van extracontractuele aansprakelijkheid gestelde vordering inwilligt en de gevorderde som toekent op grond van contractuele aansprakelijkheid, wijzigt dan ook niet het voorwerp van de vordering, zegt het Hof van Cassatie in arrest van I4 april 2005 dat het startschot was voor de 'taakformule'. ${ }^{6}$

Een andere uitspraak die feitelijke aard van het voorwerp van de vordering illustreert, is een cassatiearrest van 27 september 2013, dat ook nog voorbeelden oplevert op twee andere punten. ${ }^{64}$ De verwerende partij in cassatie vorderde 2.500 euro schadevergoeding wegens tergend en roekeloos geding en 900 euro rechtsplegingsvergoeding. Het hof van beroep, dat de maximale rechtsplegingsvergoeding van 2.000 euro toekent nadat het de vordering opnieuw omschrijft als een vordering ertoe strekkende de maximumrechtsplegingsvergoeding te verkrijgen, verhoogt het bedrag van de rechtsplegingsvergoeding niet ambtshalve, maar doet uitspraak over de vordering van de verwerende partij in cassatie binnen de perken ervan, aldus het Hof van Cassatie.

Ook als de eisende partij het voorwerp van haar vordering eerder juridisch formuleert, kan men daarin een feitelijke inhoud onderkennen. De werknemer die vordert dat de rechter 'voor recht zegt' dat zijn arbeidsvoorwaarden 'onrechtmatig' gewijzigd zijn, tracht in feite te verkrijgen dat hij mag werken zoals voorheen. De werkgever die, in plaats van een werknemer te ontslaan, de nietigverklaring of de gerechtelijke ontbinding vordert van de arbeidsovereenkomst, wil eigenlijk de werknemer weg uit zijn onderneming. De werknemer van het eerste, de werkgever van het tweede voorbeeld wil bevrijd zijn van de economische, morele en sociale last die de naleving van de verplichtingen van de overeenkomst (voor de werknemer: de gewijzigde overeenkomst) voor hem meebrengt. ${ }^{65}$

\subsubsection{De partijen en het voorwerp van de vordering}

I8. Het bepalen van het voorwerp van de vordering behoort tot het exclusieve domein van de partijen. De partijen zijn meester over hun vorderingen (en verweer). $\mathrm{Zij}$ alleen beschikken daarover. Men spreekt dan ook van 'het beschikkingsbeginsel' of

63 Cass. I4 april 2005, C.03.0I48.F.

64 Cass. 27 september 2013, C.I2.038I.F. Zie voor de twee andere punten de nrs. 45 en 59.

65 Vgl. J. F. VAN DROOGHENBROECK, «La requalification judiciaire du contrat et des prétentions qui en découlent», in P. WERY en S. STIJNS (eds.), De rol van de rechter in het contract, Brugge, Die Keure, 20I4, 59: de eiser streeft in dergelijke gevallen naar «l'anéantissement du rapport juridique», wat een (rechts)feitelijk gegeven is. 
van het 'algemeen rechtsbeginsel betreffende de autonomie der procespartijen' ${ }^{66}$ Een enkele keer verwoordt het Hof van Cassatie een aspect daarvan als 'het algemeen rechtsbeginsel dat de rechter verbiedt uitspraak te doen over niet-gevorderde zaken'. ${ }^{67}$

Het beschikkingsbeginsel heeft, zoals blijkt uit sommige van de gebruikte termen, in België de status van een algemeen rechtsbeginsel. ${ }^{68}$ Een positiefrechtelijke concretisering daarvan is terug te vinden in artikel $\mathrm{II}_{3} 8,2^{\circ}$, van het Gerechtelijk Wetboek, dat bepaalt dat een partij zich in cassatie kan voorzien tegen een in laatste aanleg gewezen beslissing waarbij uitspraak werk gedaan over niet gevorderde zaken of meer werd toegekend dan er gevraagd was.

I9. Aangezien de partijen meester zijn over hun vorderingen kunnen zij in de loop van het geding, zelfs in een andere instantie, het voorwerp van hun vordering wijzigen en uitbreiden, althans onder bepaalde voorwaarden en binnen bepaalde procedurele en materieelrechtelijke (bv. op het vlak van de verjaring) grenzen. ${ }^{69}$

\subsubsection{De rechter en het voorwerp van de vordering}

20. Op grond van het beschikkingsbeginsel mag de rechter het voorwerp van de vordering niet ambtshalve wijzigen, hetzij door dat uit te breiden, hetzij door het door een ander te vervangen. De rechter kan dus, na het voorwerp van de vordering te hebben verworpen, dat niet ambtshalve vervangen door een niet-gevorderde veroordeling. ${ }^{70}$

De 'taakformule' van het Hof van Cassatie zegt het uitdrukkelijk: de rechter mag het voorwerp van de vordering niet wijzigen. Hij mag het niet uitbreiden, noch vervangen door een ander voorwerp, ook niet om een bepaling toe te passen die van openbare orde is. ${ }^{71}$ De rechtsgrond van de vordering valt, behalve indien de partijen expliciet bepaalde rechtsgronden uitsluiten of zich expliciet tot welbepaalde rechtsgronden beperken, ${ }^{72}$ niet onder het beschikkingsbeginsel. Wanneer de rechter ambtshalve de rechtsgrond aanvult, wijzigt of vervangt, schendt hij dat beginsel

66 Het is altijd 'op voorzet' van de eiser tot cassatie dat het Hof zelf die term gebruikt: Cass. I3 juni I994, S.93.0128.N; Cass. 24 februari 1997, S.96.0013.N; Cass. 2I juni 200I, C.00.0137.N; Cass. I8 april 2005, S.04.0174.F; Cass. 20 februari 2006, C.04.0366.N; Cass. 22 januari 2007, S.04.0088. N-S.04.0169.N en Cass. I7 september 2010, C.09.0572.N.

67 Cass. 22 april 1993 , AR 8875.

68 Cass. 28 oktober 20II, Pas. 20II, 2392; Cass. I8 september 20I4, C.I2.0237.F; Cass. 20 januari 2006, Arr. Cass. 2006, I9I.

69 Het principe van de wijzigingsmogelijkheid is vervat in de artikelen 807 tot en met 8Io van het Gerechtelijk Wetboek, die hoofdstuk I (Tussenvorderingen) van titel III van boek II van het tweede deel van dat wetboek vormen.

70 Cass. 20 februari 2002, Arr. Cass. 2002, 560; Cass. 2 december 2004, Arr. Cass. 2004, I939; Cass. I december 2014, C.I3.0087.F.

7 I Cass. 28 september 20I2, C.I2.0049.N.; J. VAN DROOGHENBROECK «La requalification judiciaire du contrat et des prétentions qui en découlent» in P. WERY, S. STIJNS (eds.), De rol van de rechter in het contract, Brugge, Die Keure, 20I4, 57, nr. 58. Zelfs artikel 6 van de Arbeidsongevallenwet, dat de rechter verplicht na te gaan of alle bepalingen van de wet werden nageleefd, laat de rechter niet toe voorwerp van de vordering te wijzigen. 
dan ook niet als hij daarbij steunt op feiten die regelmatig aan zijn beoordeling zijn voorgelegd. ${ }^{73}$

Het respect van de rechter voor het voorwerp van de vordering zoals de partijen die al dan niet na aanpassingen of aanvullingen uiteindelijk stellen, kan van uit twee invalshoeken worden bekeken: een kwalitatieve en een kwantitatieve.

\subsubsection{Kwalitatieve benadering door de rechter van het voorwerp van de vordering}

2I. Lange tijd gaf het Hof van Cassatie een juridische invulling aan het begrip voorwerp van de vordering. ${ }^{74}$ Naar analogie met wat gebeurd is ten aanzien van het oorzaakbegrip, ${ }^{75}$ lijkt het Hof echter sinds kort de voorkeur te geven aan een meer feitelijke invulling van het voorwerp van de vordering. ${ }^{76} \mathrm{Ik}$ schrijf'lijkt', want in heel duidelijke termen heeft het Hof van Cassatie zich daarover (nog?) niet uitgesproken. Het is vooralsnog een kwestie van afleiding.

Neemt men aan dat de feitelijke benadering ('la conception factuelle') thans prevaleert, dan moet de rechter nagaan welk feitelijk resultaat de eiser uiteindelijk beoogt met zijn vordering en is hij gehouden te onderzoeken welke rechtsregels moeten worden toegepast om tot dat resultaat te komen. Hij moet daarbij het voorwerp van de vordering kwalificeren, desnoods zelfs diskwalificeren en herkwalificeren. ${ }^{77}$ Zo moet hij, wanneer hij kennis neemt van een vordering op grond van quasi-delictuele aansprakelijkheid, op grond van de feiten die de eiser tot staving van zijn vordering aanvoert, nagaan of de verwerende partij niet contractueel aansprakelijk is. ${ }^{78}$ Is het uiteraard de eiser die het voorwerp van zijn vordering bepaalt, dat betekent dus niet dat de rechter in dat verband lijdzaam moet toezien. Hij mag en moet het door de eiser gewenste feitelijk resultaat distilleren uit de vordering zoals ze is gesteld en de feiten die de eiser daarvoor aanvoert. Daarbij kan hij de eiser die zijn vordering onbeholpen of fout verwoordt, te hulp schieten.

73 Cass. 26 maart 2006, C.05.0360.F.

74 Toch is er ook oudere rechtspraak die het voorwerp van de vordering eerder feitelijk benadert. In de bodemprocedure van een zaak waarin het Hof van Cassatie op 26 mei r97I uitspraak deed, vorderde een werknemer de betaling van een 'verbrekingsvergoeding' op grond van de overweging dat de werkgever, door te weigeren hem toe te laten het werk te hervatten na een periode van arbeidsongeschiktheid, de arbeidsovereenkomst onrechtmatig had beëindigd. De feitenrechter stelde vast dat de werkgever de arbeidsovereenkomst niet had 'verbroken', maar kende de gevorderde bedragen toe als schadevergoeding wegens schorsing van de arbeidsovereenkomst. In het cassatiemiddel werd een schending van artikel $\mathrm{II}_{3} 8,2^{\circ}$, van het Gerechtelijk Wetboek en van het beschikkingsbeginsel aangevoerd, maar het Hof van Cassatie wees het middel af (Cass. 26 mei I97I, Arr. Cass. I97I, 958, andersluidende conclusie van L. DUCHATELET).

75 Zie nr. 47.

76 Zie over die evolutie uitgebreid J. F. VAN DROOGHENBROECK, «La requalification judiciaire du contrat et des prétentions qui en découlent», in P. WERY en S. STIJNS (eds.), De rol van de rechter in het contract, Brugge, Die Keure, 20I4, 58-70.

77 J. VAN DROOGHENBROECK «La requalification judiciaire du contrat et des prétentions qui en découlent» in P. WERY, S. STIJNS (eds.), De rol van de rechter in het contract, Brugge, Die Keure, 20I4, nr. 67.

78 Cass. I4 april 2005, C.03.or48.F. 
De hieronder besproken cassatierechtspraak toont aan hoe vermetel het zou kunnen zijn te besluiten dat de strijd op dit punt gestreden is.

22. De vraag wat het voorwerp van de vordering eigenlijk is en wat de rechter daaromtrent mag of moet doen, is prominent aan bod gekomen in de cassatierechtspraak m.b.t. loonvorderingen van werknemers.

In België is de rechtsgrond voor dergelijke vorderingen vaak een misdrijf en niet de individuele arbeidsovereenkomst of de collectieve arbeidsovereenkomst die de loonafspraak bevat, omdat de verjaringstermijn voor vorderingen op grond van een misdrijf langer is dan die voor vorderingen op grond van een overeenkomst. ${ }^{79}$ Daarom vorderen werknemers die een loonvordering instellen na het verstrijken van de verjaringstermijn die geldt voor hun vordering als zij die instellen op grond van de overeenkomst, vaak, in de plaats van loon van hun werkgever, schadevergoeding voor het verlies dat zij hebben geleden door het feit dat hun werkgever zich schuldig heeft gemaakt aan het misdrijf dat bestaat in het niet-correct betalen van het loon of het niet-respecteren van de bepalingen van een algemeenbindendverklaarde collectieve arbeidsovereenkomst. ${ }^{80}$

Aanvankelijk nam het Hof van Cassatie aan dat een werknemer bij een vordering op grond van een misdrijf geen loon als zodanig kan vorderen, maar enkel een schadevergoeding waarvan het bedrag gelijk is aan dat van het loon. Arresten van feitenrechters die een schadevergoeding toekenden op vorderingen waarvan het voorwerp was geformuleerd als loon of loonachterstallen en waarvan de rechtsgrond, met het oog op de verjaringstermijn, een misdrijf was, werden door het Hof vernietigd wegens wijziging van het voorwerp van de vordering en dus schending van het principe van de autonomie van de procespartijen vervat in artikel $1138,2^{\circ}$, van het Gerechtelijk Wetboek. ${ }^{81}$ In navolging van die rechtspraak ging ook een belangrijk deel van de rechtsleer ervan uit dat een vordering tot betaling van achterstallig loon en een vordering tot betaling van een schadevergoeding gelijk aan het bedrag van dat loon, een ander voorwerp hebben. ${ }^{82}$

In drie arresten, een van 2006 en twee van 2007, wijzigde het Hof zijn zienswijze en besliste het dat de verjaringstermijn van de burgerlijke vordering op grond van een misdrijf van toepassing is 'op elke burgerlijke rechtsvordering die gestoeld is op feiten die het bestaan van een misdrijf doen blijken, zelfs wanneer die feiten een contractuele

79 Vijf jaar zonder langer te kunnen zijn dan één jaar na het einde van de arbeidsovereenkomst (art. I5 Arbeidsovereenkomstenwet) als de vordering ex contractu wordt ingesteld, vijf jaar zonder meer als zij ex delicto wordt ingesteld (art. 26 Voorafgaande titel van het Wetboek van strafvordering, dat verwijst naar art. 22262 bis BW).

$80 \quad$ Art. I62 en 189 Sociaal Strafwetboek.

8I Cass. I3 juni 1994, Arr. Cass. I994, 6oI; Cass. I8 juni 2000, Arr. Cass. 2000, II45; Cass. 2 april 200I, Arr. Cass.2001, 579, RW 200I-2002, I32I, noot M. DE VOS; Cass. 9 september 2002, JTT 2002, 457 .

82 M. DE VOS, 'Schadeherstel ex delicto versus rechtsherstel of loon ex contractu', RW 200I-2002, I322; J. HERMAN, 'Behandeling van de zaak', in G. VAN LIMBERGHEN (ed.), Sociaal procesrecht, Antwerpen, Maklu, I995, 217. 
tekortkoming van de verweerder uitmaken en het voorwerp van de vordering in de uitvoering van die contractuele verbintenis bestaat als herstel in natura'. ${ }^{83}$

Het is hier niet de plaats om in te gaan op de problematiek van de verjaring van loonvorderingen. Van belang voor ons onderwerp is alleen dat de bedoelde arresten diverse auteurs ertoe hebben gebracht te stellen dat zij een ommekeer betekenen in de rechtspraak van het Hof van Cassatie wat betreft de invulling van de noties voorwerp en oorzaak van de vordering. ${ }^{84}$ Met name zou het Hof in die arresten een feitelijke benadering hebben onderschreven van het voorwerp van de vordering. ${ }^{85}$ Twijfel daarover is echter mogelijk, aangezien het Hof in die arresten nergens spreekt over het voorwerp van de vordering of het beschikkingsbeginsel, maar enkel beslist dat op grond van een misdrijf loon kan worden gevorderd, zij het als herstel in natura van de door een misdrijf geleden schade. In het arrest van 23 oktober 2006 werd in het cassatiemiddel zelfs geen schending van het beschikkingsbeginsel of van artikel II $38,2^{\circ}$ van het Gerechtelijk Wetboek opgeworpen.

Dat laatste was wel het geval in de middelen die werden ingeroepen in de zaken waarin de twee arresten van 22 januari 2007 werden gewezen. ${ }^{86}$ Die zaken hadden betrekking op het volgende. Stelde een werknemer zijn loonvordering in als een vordering tot het verkrijgen van schadevergoeding, dan eiste hij in de regel een bedrag gelijk aan het nettoloon dat hij zou hebben ontvangen als de werkgever zich niet schuldig zou hebben gemaakt aan een van de voormelde misdrijven en zelfs al vorderde hij brutoloon, hij kreeg maar een bedrag gelijk aan het nettoloon toegekend. Toch was zijn schade groter. Weliswaar zou hij bij een correcte naleving van de loonbetalingsverplichtingen van zijn werkgever slechts het nettoloon hebben ontvangen en niet de socialezekerheidsbijdragen (en de fiscale inhouding die bedrijfsvoorheffing wordt genoemd) die daarop diende te worden ingehouden. Maar die socialezekerheidsbijdragen zijn niet alleen een belangrijke bron van financiering van zijn socialezekerheidsbescherming, maar soms ook vereist om die bescherming te kunnen genieten. Om maar één aspect te vermelden, voor de samenstelling van de pensioenloopbaan en de berekening van het pensioenbedrag wordt enkel rekening gehouden met arbeidsperiodes waarvoor op het loon socialezekerheidsbijdragen zijn afgehouden en doorgestort. Op schadevergoeding zijn volgens de socialezekerheidswetgeving geen socialezekerheidsbijdragen verschuldigd, zodat de toekenning daarvan niet in aanmerking komt voor de pensioenopbouw.

83 Cass. 23 oktober 2006, JTT 2007, 227, gelijkluidende concl. J.F. LECLERCQ; Cass. 22 januari 2007, S.04.0165.N, JTT 2007, 289; Cass. 22 januari 2007, S.04.0088.N S.04.0169N, JTT 2007, 48I, noot F. LAGASSE en M. PALUMBO, RCJB 2008, I68, noot F. KÉFER. Zie ook Cass. 20 april 2009, S.o8.00I5.N.

84 R. CAPART, 'La Cour de cassation consacre la conception factuelle de l'objet de la demande en justice' (noot onder Cass. 23 oktober 2006), RRD 2006, 233; F. LAGASSE en M. PALUMBO, 'Action civile naissant d'un délit, délai de prescription et Cour de cassation. Analyse des arrêts rendus le 23 octobre 2006 et le 22 janvier 2007 par la Cour de cassation', JTT 2007, 473.

85 Lagasse en Palumbo stellen 'concernant la problématique de la qualification de l'objet de la demande et de sa cause, les arrêts du 23 octobre 2006 et du 22 janvier 2007 constituent un spectaculaire revirement de jurisprudence' (F. LAGASSE en M. PALUMBO, l.c., 478).

86 Cass. 22 januari 2007, S.04.0088.N en S.04.0169.N. 
De werknemer die een loonvordering instelt op grond van een misdrijf, wil eigenlijk niet alleen vergoeding voor het directe verlies van zijn nettoloon, maar ook het ongedaan maken van de nadelige socialezekerheidsgevolgen die de niet-correcte betaling van het loon meebrengt.

23. In de zaak die leidde tot het eerste cassatiearrest van 22 januari 2007, eiste een werkneemster een bedrag gelijk aan het brutoloon als herstel in natura. ${ }^{87}$ In graad van beroep veroordeelde het arbeidshof de werkgever tot het betalen aan de werkneemster van het door haar gevorderd brutobedrag van de niet-betaalde lonen 'te verminderen met de aan de bevoegde instellingen over te maken op dit loon verschuldigde bedrijfsvoorheffing en socialezekerheidsbijdragen'. In het cassatiemiddel waarmee hij dat arrest bestreed, voerde de werkgever aan dat het arbeidshof zelf in het bestreden arrest had vastgesteld dat de schade van de werkneemster, die gelijk is aan het brutobedrag van de haar niet uitbetaalde lonen, bestaat uit de gederfde netto-inkomsten enerzijds, de schade uit de nadelige repercussies die voortvloeien uit het feit dat de loontekorten niet het voorwerp hebben uitgemaakt van een bijdragestorting in de sociale zekerheid, anderzijds. Welnu, aldus het cassatiemiddel, de werkneemster vorderde geen vergoeding voor de schade uit de nadelige repercussies die zouden voortvloeien uit het feit dat de loontekorten niet het voorwerp van een bijdragestorting in de sociale zekerheid hebben uitgemaakt. Door de eiseres te veroordelen tot betaling van een vergoeding voor de door verweerster gederfde netto-inkomsten, evenals voor schade uit nadelige repercussies die voortvloeien uit het feit dat de loontekorten niet het voorwerp hebben uitgemaakt van een bijdragestorting in het socialezekerheidsstelsel voor werknemers, zodat de totale door de eiseres verschuldigde vergoeding gelijk is aan het niet-betaalde brutoloon, kende het arbeidshof aan de werkneemster een niet-gevorderde vergoeding toe en schond het het beschikkingsbeginsel, aldus nog altijd het middel van de werkgever.

Het Hof van Cassatie verwierp het middel op de overweging dat uit de stukken waarop het vermag acht te slaan, blijkt dat de werkneemster de betaling van brutobedragen aan achterstallig loon vorderde bij wijze van herstel in natura. Door de werkgever te veroordelen tot het betalen aan de werkneemster van het door haar gevorderd brutobedrag van de niet-betaalde lonen, te verminderen met de aan de bevoegde instellingen over te maken op dit loon verschuldigde bedrijfsvoorheffing en socialezekerheidsbijdragen, kende het arrest het gevorderd herstel in natura toe en werd de werkneemster teruggeplaatst in de toestand waarin zij zich zou hebben bevonden indien het misdrijf niet was gepleegd. Het arbeidshof miskende aldus niet het algemeen rechtsbeginsel betreffende de autonomie der procespartijen, aldus nog het Hof.

Aangezien in deze zaak niet echt sprake is van herkwalificatie van het voorwerp van de vordering door de feitenrechter, is het betwistbaar dat dit arrest de aanzet

87 Het cassatiemiddel vermeldt 'In besluiten stelde de verweerster [d.i. werkneemster] dat zij aanspraak maakte op brutobedragen omdat zij betaling van loon als herstel in natura vorderde en dat op de gevorderde bedragen in die hypothese ook sociale zekerheidsbijdragen verschuldigd zijn (syntheseberoepsconclusie, p. 18, in fine)'. 
zou vormen tot de nieuwe, feitelijke invulling van het begrip 'voorwerp' van de vordering.

24. En dat is eigenlijk ook het geval met het tweede arrest van 27 januari 2007 . Volgens de eiseres tot cassatie, de werkgever, zou de feitenrechter het beschikkingsbeginsel hebben geschonden door een vordering tot betaling van achterstallig loon toe te wijzen alsof het een vordering tot schadevergoeding wegens het misdrijf bestaande uit het niet-betalen van loon betrof. De vordering van de werknemer strekte echter niet tot de betaling van achterstallig loon als zodanig, maar tot de betaling van loonachterstallen als het herstel in natura wegens het misdrijf bestaande uit het niet betalen van loon. Dit doet, zo wierp de werkgever in zijn cassatiemiddel op, evenwel geen afbreuk aan de vaststelling dat de vordering strekt tot betaling van loon als zodanig, wat een contractuele vordering is, die niet kan worden geacht ex delicto te zijn ingesteld.

Zoals in de overige hierboven besproken arresten overweegt het Hof van Cassatie ook in het in deze zaak gewezen arrest dat een vordering wel degelijk ex delicto is ingesteld wanneer loon wordt gevorderd als herstel in natura van als gevolg van een misdrijf geleden schade. Gelet op die overweging kan niet langer worden aangenomen dat de vordering tot betaling van loon als herstel in natura, een contractuele vordering is. Bijgevolg is er ook hier geen sprake van enige herkwalificatie van het voorwerp van de vordering, wat verklaart waarom het Hof van Cassatie beslist dat het arbeidshof het beschikkingsbeginsel niet heeft geschonden door de vordering van de werknemer te beschouwen als een burgerlijke vordering voortvloeiend uit een misdrijf (met als gevolg dat de werknemer zich op de gunstigere verjaringstermijn kan beroepen die geldt voor burgerlijke vorderingen op grond van een misdrijf).

Gelet op wat voorafgaat, kan m.i. in de arresten van 23 oktober 2006 en 22 januari 2007 , anders dan wordt beweerd, geen kentering worden gezien van de cassatierechtspraak in de zin dat het Hof een feitelijke interpretatie van het voorwerp van de vordering heeft onderschreven. Daaruit is wel af te leiden dat in de aangelegenheid van de loonvorderingen de kwalificatie van minder belang wordt. Er kan nu immers ook loon ex delicto worden gevorderd, met name als herstel in natura.

25. In een cassatiearrest van Io februari 2014 heeft het Hof van Cassatie volgens Van Drooghenbroeck op spectaculaire wijze gebroken met de visie dat het voorwerp van de vordering een juridische in plaats van een feitelijke inhoud heeft. ${ }^{88}$

In de zaak waarin dat arrest werd gewezen, vorderde de eiser de nietigverklaring van een overeenkomst wegens benadeling voor meer dan zeven twaalfden bij verkoop van onroerende goederen. ${ }^{89}$ De partijen beperkten hun discussie tot de

88 J. F. VAN DROOGHENBROECK, «La requalification judiciaire du contrat et des prétentions qui en découlent», in P. WERY en S. STIJNS (eds.), De rol van de rechter in het contract, Brugge, Die Keure, 20I4, 65 .

89 Art. I674 BW: 'Indien de verkoper in de verkoopprijs van een onroerend goed voor meer dan zeven twaalfden is benadeeld, heeft hij het recht om de vernietiging van de koop te eisen, ook al had hij bij het contract uitdrukkelijk afstand gedaan van het recht om die vernietiging te vorderen, en al had hij verklaard de meerdere waarde te schenken.' 
benadeling bij de verkoop van onroerende goederen en de eiser riep op geen enkel ogenblik de benadeling voor meer dan één vierde in die geldt bij verdelingen. ${ }^{\circ}$ Het hof van beroep was van oordeel dat de overeenkomst niet als een verkoop van onroerende goederen moet beschouwd worden, maar als een 'afstand van rechten met declaratief karakter'. Na te hebben vastgesteld dat de eiser geen beroep heeft gedaan op de benadeling voor meer dan één vierde, verklaarde het de overeenkomst rechtsgeldig.

Het Hof van Cassatie vernietigde dat arrest: de feitenrechter miskent door zo te oordelen het algemeen rechtsbeginsel dat de rechter gehouden is het geschil te beslechten overeenkomstig de daarop van toepassing zijnde rechtsregels, aldus het Hof. ${ }^{\text {II }}$ De eiser had de nietigverklaring, d.w.z. de verdwijning, gevorderd van de overeenkomst en de daaruit voortvloeiende rechten en verplichtingen. Het is op dat voorwerp van de vordering dat de rechter het recht moet toepassen.

Of dat nu betekent dat het voorwerp van de vordering geen enkel juridisch kantje meer vertoont, valt te betwijfelen. De problematiek van de loonvorderingen toont duidelijk aan dat dit soms toch nog het geval is. Wanneer een werknemer die te weinig loon heeft ontvangen, een geldsom vordert (feitelijk voorwerp) is het niet zonder belang dat hij bij de omschrijving van het voorwerp van zijn vordering aanduidt wat de aard is van de gevorderde bedragen: wordt de geldsom gevorderd als achterstallig loon als zodanig of als achterstallig loon bij wijze van herstel in natura, dan wel als een schadevergoeding? Dat is van belang omdat als hij loon als zodanig of bij wijze van herstel in natura toegewezen krijgt, op het verkregen bedrag werknemersbijdragen in mindering moet worden gebracht, wat niet het geval is met een schadeloosstelling, die vrij is van socialezekerheidsbijdragen. Men kan dan ook niet aanvaarden dat wanneer een werknemer bv. om die reden ervoor kiest schadevergoeding en geen loon te vorderen, hij het gevaar loopt dat de rechter zijn vordering herkwalificeert in een vordering tot het verkrijgen van loonachterstallen als herstel in natura, waarop wel socialezekerheidsbijdragen moeten worden ingehouden. Ook het verweer tegen een vordering van de werknemer m.b.t. loon kan verschillend zijn naargelang hij loon vordert dan wel een schadevergoeding gelijk aan het loon. Nog een voorbeeld: als een van de partijen bij een arbeidsovereenkomst de gerechtelijke ontbinding vordert van de arbeidsovereenkomst en dus de verdwijning van de economische, morele en sociale contraintes die de overeenkomst meebrengt (feitelijk voorwerp), mag dan de rechter de nietigverklaring uitspreken als hij vindt dat die rechtsfiguur beter past bij de feitelijke gegevens die voorliggen? De eerste weg opent bv. de poort om schadevergoeding te eisen wijder dan de eerste en is wellicht om die reden gekozen. ${ }^{92}$ Herkwalificeren lijkt in dat geval niet altijd in overeenstemming te brengen met het beginsel van de autonomie van de procespartijen. De rechter lijkt bij zijn benietiging, wanneer een medeërfgenaam bewijst dat hij voor meer dan een vierde benadeeld is. [...].'

9 I Cass. Io februari 2014, C.I3.038r.N.

92 Artikel II84 van het Burgerlijk Wetboek kent expliciet een recht op schadevergoeding toe. 
slissing dus soms ook de omschrijving van de juridische aard van het voorwerp van de vordering te moeten respecteren, zo niet miskent hij het beschikkingsbeginsel en artikel II $38,2^{\circ}$ van het Gerechtelijk Wetboek.

De juiste conclusie lijkt dan ook te zijn dat de vaststelling dat het voorwerp van de vordering niet altijd louter feitelijk is, maar soms ook in zekere mate dient te worden gejuridiseerd. ${ }^{93}$

26. Dat was naar mijn oordeel tot voor kort ook de mening van het Hofvan Cassatie, ${ }^{94}$ zoals naar voren komt in een aantal arresten gewezen in niet-sociale zaken.

Een arrest van het Hof van Cassatie van 8 februari 200I heeft betrekking op de omgekeerde situatie van die welke hierboven werd geschetst m.b.t. een vordering tot gerechtelijke ontbinding van een arbeidsovereenkomst die de rechter zou herkwalificeren als een vordering tot nietigverklaring. In het bestreden arrest had het hof van beroep de ontbinding van een verkoopovereenkomst uitgesproken wegens ernstige wanprestatie van de verkoper, die had nagelaten een conforme levering te doen, door goederen (boter) te leveren met een gewijzigde vervaldatum. In zijn vordering kwalificeerde de koper die wijziging van de vervaldatum evenwel niet als een contractuele wanprestatie, maar als bedrog in de precontractuele fase, op grond waarvan hij niet de ontbinding wegens wanprestatie vorderde, maar de nietigverklaring wegens wilsgebrek. Door zo te oordelen heeft het hof van beroep, aldus het Hof van Cassatie, het voorwerp en de oorzaak van de vordering gewijzigd, en derhalve artikel II $38,2^{\circ}$ van het Gerechtelijk Wetboek en het beschikkingsbeginsel miskend. Nochtans kan moeilijk worden betwijfeld dat het economisch voordeel dat werd gevorderd erin bestond dat de overeenkomst werd ongedaan gemaakt, wat net zo goed wordt bereikt door de ontbinding als door de vernietiging van de verkoopovereenkomst. ${ }^{95}$ Ook dit arrest toont m.i. aan dat het Hof van Cassatie geen louter feitelijke benadering van het voorwerp van de vordering hanteert.

In een arrest van 20 februari 2002 vernietigt het Hof een in graad van beroep gewezen vonnis een feitenrechter wegens miskenning van artikel $13_{3} 8,2^{\circ}$ van het Gerechtelijk Wetboek. De eisende partij had een schadevergoeding gevorderd voor de door een ongeval veroorzaakte arbeidsongeschiktheid. Zij begrootte de schadevergoeding op grond van voltijds loon, terwijl zij op het ogenblik van het ongeval slechts deeltijds was tewerkgesteld. De rechtbank bepaalde de schadevergoeding op basis van het deeltijdse loon, maar kende daarboven een schadevergoeding toe voor het verlies van een kans tijdens de ongeschiktheid opnieuw voltijds te gaan werken. Het Hof van Cassatie overweegt dat door zo te oordelen de feitenrechter het voorwerp van de vordering heeft gewijzigd in strijd met het bepaalde in artikel $\mathrm{II} 38,2^{\circ}$, van het Gerechtelijk Wetboek. Nochtans kan moeilijk worden betwist dat de betaling van een geldsom werd gevorderd, ter compensatie van de inkomensderving die

93 Ph. THION, 'Kwalificatie van oorzaak en voorwerp van de vordering. Mysteries uit het procesrecht', NJW 2003, afl. 36, 732.

94 Is van het tegendeel overtuigd: J.F. Van Drooghenbroeck, Cassation et juridiction. Iura dicit curia, Brussel, Bruylant, 2004, 240-24I.

95 Dat is dan ook de kritiek op dat arrest van J.F. Van Drooghenbroeck, Cassation et juridiction. Iura dicit curia, Brussel, Bruylant, 2004, 236-237. 
het gevolg was van het door de fout van de verwerende partij veroorzaakte ongeval, en dat het ook dit is dat werd toegekend. Het economisch voordeel (de geldsom) die werd gevorderd, was bovendien niet groter dan de door de feitenrechter toegekende bedragen, wat m.i. bevestigt dat het Hof van Cassatie aan het voorwerp van de vordering geen louter feitelijke invulling geeft.

Maar, het moet worden erkend, die arresten dagtekenen van vóór dat van ro februari 20I4.

27. Ik denk dat op grond van wat voorafgaat, ook kan worden gezegd dat de in het preadvies-Asser gestelde vraag of de rechter een lager bedrag mag toekennen dan wat de eiser vordert, nl. het lagere bedrag dat op een andere rechtsgrond verschuldigd is ${ }^{96}$ in België positief zou worden beantwoord. Ik neem een fictief voorbeeld dat vergelijkbaar is met de vordering die aan de orde was in het arrest van de Hoge Raad van 17 oktober 2014 waarnaar Asser verwijst.

Een werkman ${ }^{97}$ die op grond van de (Arbeidsovereenkomsten)wet enkel voor de eerste twee weken waarin hij arbeidsongeschikt is wegens ziekte of ongeval, recht heeft op een loondervingsvergoeding van zijn werkgever gelijk aan het loon,,$^{98}$ die men 'gewaarborgd loon' noemt, vordert voor een derde en een vierde week arbeidsongeschiktheid van zijn werkgever een bedrag gelijk aan zijn gewone loon als 'gewaarborgd loon'. Die vordering kan niet worden ingewilligd, want de wet voorziet niet in een (volledig) 'gewaarborgd loon' voor die derde en vierde week. Er bestaat echter wel een algemeenbindendverklaarde interprofessionele collectieve arbeidsovereenkomst die alle werkgevers van de particuliere sector bindt, die werklieden voor de derde en de vierde week ten laste van de werkgever een aanvulling toekent boven de arbeidsongeschiktheidsuitkering waarin die de ziekteverzekering voor die weken voorziet, met name een 'vergoeding' die gelijk is aan een bepaald percentage van zijn gewone loon, minder dus dan het gevorderde normale loon. ${ }^{99}$ Het lijdt naar mijn oordeel geen twijfel dat de rechter de werkman de vergoeding van de cao kan en zelfs moet toekennen: de werknemer heeft van zijn werkgever een loondervingsvergoeding gevraagd gelijk aan honderd procent van zijn normale loon. Maar uit de toepasselijke bepalingen blijkt dat hij in ieder geval, zij het op een andere rechtsgrond (de CAO nr. I2bis) dan door hem ingeroepen (de Arbeidsovereenkomstenwet) recht had op een lager percentage daarvan, zodat de rechter dat bedrag moet toekennen.

96 ASSER, onder 3.2 en voetnoot 4I.

97 In België bestaat dat species, de zgn. Wet Eenheidsstatuut van 26 december 2013 ten spijt, nog altijd. Het gaat om een werknemer die hoofdzakelijk handarbeid verricht (art. 2 Arbeidsovereenkomstenwet). Vrouwelijke werklieden worden werksters genoemd.

98 Voor de tweede week dan nog enkel tot beloop van zestig procent van zijn loon, dat dan nog eens begrensd wordt: art. 52 Arbeidsovereenkomstenwet.

99 Art. 3 en 4 van de collectieve arbeidsovereenkomst nr. I2bis van 26 februari 1979 tot aanpassing van de collectieve arbeidsovereenkomst nr. I2 van 28 juni 1973 betreffende het toekennen van een gewaarborgd maandloon aan de werklieden in geval van arbeidsongeschiktheid ingevolge ziekte, ongeval van gemeen recht, arbeidsongeval of beroepsziekte aan de wet van 3 juli I 978 betreffende de arbeidsovereenkomsten, gewijzigd door de collectieve arbeidsovereenkomsten nr. I2ter van I februari I983, nr. I2quater van 6 december I983, nr. I2quinquies van I6 december ig86 en $\mathrm{nr}$. I2sexies van 28 juli ig92. 
3.2.3.2 Kwantitatieve benadering door de rechter van het voorwerp van de vordering

28. De kwantitatieve benadering van het voorwerp van de vordering waartoe het beschikkingsbeginsel de rechter verplicht, wordt vooral geformuleerd als het verbod meer toe te kennen dan wordt gevorderd. Soms wordt dit in een cassatiemiddel verwoord als 'het algemeen rechtsbeginsel dat de rechter verbiedt meer toe te kennen dan gevorderd werd'. ${ }^{\text {100 }}$

Maar dat is maar één aspect van die kwantitatieve benadering. Die houdt, algemener uitgedrukt, in dat de rechter in beginsel enkel mag oordelen binnen de grenzen van wat gevorderd is. Hij mag niet alleen niet meer toekennen dan gevorderd werd (ultra petita), maar ook geen uitspraak doen over niet-gevorderde zaken (extra petita), of nalaten een punt van de vordering te beslechten (infra petita). ${ }^{\text {ror }}$

29. Het is het beschikkingsbeginsel dat de belangrijkste concretisering is van het beginsel dat de partijen de leiding van het burgerlijk geding hebben. Zoals hieronder nog zal blijken, behoort de rechtsgrond van de vordering maar tot de autonomie van de procespartijen in de mate dat zij expliciet bepaalde rechtsgronden uitsluiten of zich expliciet tot welbepaalde rechtsgronden beperken. ${ }^{\text {Io2 }}$

\subsection{De oorzaak, het voorwerp en de rechtsgrond van de vordering}

\subsubsection{De rechtsstrijd wordt gevormd door partijen}

30. Met het beginsel dat wat Nederlanders blijkbaar de 'rechtsstrijd' of 'het partijdebat' noemen - termen die Belgen, minder krijgshaftig en gereserveerder als zij zijn, doorgaans niet gebruiken, maar wel begrijpen - wordt gevormd door de partijen, zal wel iedereen het eens zijn. Het komt niet de rechter toe die strijd of dat debat te beperken of uit te breiden. Dat is precies het effect van het hierboven besproken algemeen rechtsbeginsel van de autonomie van de partijen, beschikkingsbeginsel genoemd. Het is de procesrechtelijke tegenhanger van de wilsautonomie van de partijen in het contractenrecht. ${ }^{103}$

Drukt men de grenzen aan de rechtsstrijd in Nederland uit met de formule dat de rechter beslist 'op de grondslag van hetgeen partijen aan hun vordering, verzoek of verweer ten gronde hebben gelegd', ${ }^{104}$ de 'taakformule' van het Belgische Hof van Cassatie heeft het over de gehoudenheid van de rechter 'de juridische aard te onderzoeken van de hem door de partijen voorgelegde eisen' of, in de eindversie van de formule, 'de juridische aard van de door de partijen aangevoerde feiten en handelingen [te] onderzoeken'. Het woord eisen legt eerder de klemtoon op het te kwalificeren voorwerp van de vordering, ${ }^{105}$

\footnotetext{
Ioo Cass. 22 september I992, AR 5452.

IoI Artikel II $38,3^{\circ}$, van het Gerechtelijk Wetboek.

I02 Zie nr. 34 .

I03 Zie nr. I8.

I04 Art. $24 \mathrm{Rv}$.

I05 Zie nr. 2I.
} 
de term feiten en handelingen op wat thans wordt begrepen onder de 'oorzaak' ${ }^{106}$ De laatste versie van de formule toont aan dat in België, weliswaar zonder die termen te gebruiken, nog wordt vastgehouden aan het onderscheid tussen oorzaak en rechtsgrond. Dat onderscheid wordt in de 'taakformule' zelfs duidelijker gemaakt dan vroeger, door aan de geciteerde verplichting tot onderzoek om de juridische aard van de feitelijke gegevens, de gehoudenheid van de rechter te laten voorafgaan 'het geschil te beslechten overeenkomstig de daarop van toepassing zijnde rechtsregels'. Ik vind dat een goede zaak. Het is ongetwijfeld zo dat het onderscheid tussen beide niet altijd gemakkelijk te maken is, noch altijd door de partijen wordt gemaakt. Maar moeilijk en zonder partijen gaat ook. En in ieder geval lijkt het zinvol het onderscheid aan te houden waar dat probleemloos kan. Dat doe ik dan ook.

Het zinvolle van het onderscheid blijkt alleen al uit het feit dat men in Nederland moet zeggen dat artikel 24 van het Wetboek van Burgerlijke Rechtsvordering de rechter 'in principe' bindt aan de inhoud en de omvang van 'de grondslagen' van de vordering, die zowel feitelijke als juridische elementen (rechtsregels, rechten, kwalificaties, rechtsgevolgen) bevatten), ${ }^{107}$ maar artikel 25 van hetzelfde wetboek, dat de rechter verplicht ambtshalve de rechtsgronden aan te vullen, aan dat principe zoveel afbreuk doet dat er uiteindelijk niets van overblijft. ${ }^{108}$ De Belgische benadering is op dit punt klaarder: de juridische argumenten die de partijen opwerpen, binden de rechter helemaal niet ${ }^{109}$, tenzij in het uitzonderlijke geval van een procesovereenkomst daarover.

3I. Zoals in het artikel 24 van het Nederlandse Wetboek van Burgerlijke Rechtsvordering, knoopt de 'taakformule' van het Belgische Hof van Cassatie de beslissing van de rechter aan de oorzaak (de door de partijen aangevoerde feiten, handelingen, houdingen en toestanden) en het voorwerp van de vordering. De recentste versie van de formule vangt aan met 'De rechter is gehouden het geschil te beslechten....'.

Ook het element onderzoek is in de taakomschrijving van het Hof van Cassatie terug te vinden: 'Hij moet de juridische aard onderzoeken van de hem door de partijen voorgelegde eisen' of van 'de door de partijen aangevoerde feiten en handelingen'. Of hij dit heeft gedaan en dat op wettige wijze, moet blijken uit de beslissingen en het uiteindelijke beschikkend gedeelte van de uitspraak en motivering van de beslissingen.

In obiter dicta of 'ten overvloede' gegeven redenen kan de rechter wel straffeloos - d.w.z. zonder dat zijn beslissingen die door dergelijke overwegingen niet worden gedragen, door het Hof van Cassatie op de onwettigheid van enkel die grond

Io6 In de rechtsleer bestaan of bestonden van oudsher twee opvattingen over wat 'de oorzaak' van de vordering is. De ene strekking gaat uit van een feitelijke benadering en omschrijft de oorzaak van de vordering als feiten, te onderscheiden van de rechtsregels. De tweede strekking maakt het onderscheid tussen feit en recht niet en beschouwt ook de rechtsregel of de juridische grondslag van de vordering als behorend tot haar 'oorzaak'. Zowel het Hof van Cassatie als de rechtsleer opteren thans voor een factuele invulling (concl. C. VANDEWAL vóór Cass. 29 mei 2015, C.13.0615.N). Dat in de regel dit enigszins lijkt te worden genuanceerd, werd toegelicht in de nr. 25 en 26.

I07 ASSER, onder 3.3.I.

IO8 ASSER, onder 3.4.I.

Io9 Tenzij in de gevallen waarin zij deel uitmaken van het voorwerp van de vordering. Zie nr. 26. 
kunnen worden vernietigd - de door de partijen getrokken krijtlijnen overschrijden. En hij kan de feitelijke cirkel ook enigszins vergroten door onderzoeksmaatregelen te bevelen om de partijen toe te laten het bewijs te leveren van aangevoerde feiten, naar aanleiding waarvan andere feiten aan het licht kunnen komen die vervolgens in de zaak worden betrokken. ${ }^{\text {IIo }}$

\subsubsection{De rechter mag niet treden buiten de rechtsstrijd}

\section{3·3.2.I Inleiding}

32. Het algemeen beginsel van de autonomie van de procespartijen ontneemt de rechter de bevoegdheid buiten de ring te treden waarbinnen de partijen hun geschil uitvechten. ${ }^{\text {III }}$ Hij mag zich niet uitspreken over niet-ingestelde vorderingen, het voorwerp van ingestelde vorderingen niet wijzigen of uitbreiden ${ }^{\text {II2 }}$ en de oorzaak (de feitelijke gegevens, d.i. gebeurtenissen, handelingen, houdingen en situaties die de partijen in het proces ter sprake brengen ${ }^{\mathrm{I} 3}$ ) niet vervangen, wijzigen of aanvullen. Met betrekking tot de oorzaak is er de nuance dat de onderzoeksmogelijkheden die het Gerechtelijk Wetboek de rechter ter beschikking stelt en die hij zelfs ambtshalve kan bevelen, hem op dat vlak niet volledig afhankelijk maken van de partijen. ${ }^{\text {II } 4}$

Dat hij wel de rechtsgronden van eis en verweer mag vervangen, wijzigen of aanvullen, is niet te beschouwen als een uitzondering op het autonomieprincipe, maar een bevestiging van de essentie van de rechtsprekende opdracht: 'De rechter is gehouden het geschil te beslechten overeenkomstig de daarop van toepassing zijnde rechtsregels', zo vangt de meest recente versie van de 'taakformule' van het Hof van Cassatie aan. Aangezien de rechtsregels toepassen een kerntaak van de rechter is bij het beslissen over een geschil, ligt het voor de hand dat hij het is en niet de partijen die daarbij het stuur vasthouden.

\section{3·3.2.2 Procesovereenkomsten}

33. Onder nummer 3·3.2.2 van zij preadvies behandelt Asser artikel I49 van het Wetboek van Burgerlijke Rechtsvordering. Die bepaling benoemt de bronnen waaruit de rechter de feitelijke informatie mag halen die hij aan zijn beslissing ten grondslag legt. Het gaat om alle feiten die 'in het geding aan hem ter kennis zijn gekomen of gesteld', zowel de feiten die blijken uit de door de partijen overgelegde procedureen overtuigingsstukken, als die welke mondeling door hen naar voren zijn gebracht (op een comparitie, bij een getuigenverhoor, een deskundigenonderzoek of een bezichtiging ter plaatse), alsook de feiten die de rechter op een andere wijze in het

IIO Zie hierover nr. 54 .

III Ook in bokswedstrijden blijft de scheidsrechter binnen de ringtouwen. Hij heeft er de beschikking over een trap in de zgn. neutrale hoek.

II2 Zie nr. 20.

II3 Als men 'oorzaak' opvat als alle door de partijen vermelde feiten en niet alleen de 'in het bijzonder' aangevoerde feiten. Zie hierover nr. $5 \mathrm{I}$.

II4 Zie nr. 54. 
geding ter kennis zijn gekomen (bijvoorbeeld een eigen waarneming ter zitting). De rechter mag die informatie evenwel slechts gebruiken binnen de door artikel 24 van het Wetboek van Burgerlijke Rechtsvordering gestelde grenzen van de rechtsstrijd en mag ze dus enkel betrekken bij de beoordeling van het rechtsfeit dat door de partijen als grondslag werd gesteld van hun vordering of verweer.

Omdat ik verkies de onderdelen (en de termen) voorwerp, oorzaak en rechtsgrond van de vordering aan te houden, heb ik mijn bespreking van de mogelijkheden en beperkingen die de Belgische rechter kent m.b.t. de feiten (de oorzaak) en de rechten (de rechtsgrond) geplaatst in het rijtje dat begint met de aanvullingen (en wijzigingen en vervangingen) van de rechtsgrond door de rechter. ${ }^{15} \mathrm{U}$ vindt de tegenhanger van wat Asser behandelt onder 3.3.2.2, dan ook daar, onder $3 \cdot 4 \cdot 4$.

Op deze plaats behandel ik een onderwerp dat in het Nederlandse preadvies elders maar slechts zijdelings aan bod komt, ${ }^{116}$ doch wel geregeld terug te vinden is in de rechtspraak van het Belgische Hof van Cassatie over de taak van de rechter, nl. in welke mate de partijen de grenzen van de rechtsstrijd contractueel kunnen vastleggen. Wel betwijfel ik dat dergelijke overeenkomsten in de praktijk vaak voorkomen omdat de partijen er doorgaans geen belang bij hebben te verhinderen dat de rechter het door hen beoogde in zijn uitspraak realiseert door zich te steunen op feiten die daarvoor dienstig kunnen zijn zonder dat zij dat zelf hebben gezien of door een andere rechtsgrond toe te passen dan die welke zij zelf hebben ingeroepen.

34. Volgens de rechtspraak van het Hof van Cassatie kunnen de partijen een processuele overeenkomst sluiten die de rechtsstrijd afbakent. In de sinds jaar en dag door het Hof gehanteerde bewoordingen, luidt het dat de rechter 'geen betwisting mag opwerpen waarvan de partijen in hun conclusies het bestaan hebben uitgesloten'. ${ }^{\text {II7 }}$ Ook hier speelt dus het beschikkingsbeginsel, naast zijn rol m.b.t. het voorwerp van de vordering. ${ }^{\text {I18 }}$ Dergelijke overeenkomst over de grenzen van de rechtsstrijd kan zowel betrekking hebben op de oorzaak van de vordering (de feiten) als op de rechtsgrond daarvan. De partijen zouden kunnen te kennen geven dat zij bepaalde feiten die weliswaar blijken uit de overtuigingsstukken die zijn voorgelegd, buiten het debat willen houden, zoals zij dat ook zouden kunnen doen m.b.t. bepaalde rechtsfiguren of juridische regels. In het kader van de taakformule drukt het Hof van Cassatie het als volgt uit: 'De partijen kunnen door een uitdrukkelijk procedureakkoord de rechter binden over een punt in rechte of in feite waartoe zij het debat willen beperken', ${ }^{\text {I19 }}$ onder voorbehoud weliswaar van wat de openbare orde raakt.

II5 Zie hieronder 3.4.3 (Aanvulling of wijziging van de rechtsgrond van de vordering), 3.4.4. (Aanvulling of wijziging van de oorzaak van de vordering) en 3.4.5 (Aanvulling of wijziging van het voorwerp van de vordering), de nrs. 38 e.v.

II6 Zie het arrest van de Hoge Raad in de zaak Post tegen Kleijweg, besproken onder 3.4.3. de laatste alinea en onder 3.4 .4 , tweede alinea.

II7 Cass. 3I maart I978, Arr. Cass. I978, II, 865; Cass. I9 september I980, Arr. Cass. I980, I, 67; Cass. 5 oktober 1984, Arr. Cass. 1984, 21.

II8 Zie de nrs. I8 en 20.

II9 Cass. 28 september 20I2, C.I2.0049.N. 
Uit de gebruikte formulering blijkt dat enkel uitdrukkelijke procedureakkoorden worden aanvaard. Een impliciet procedureakkoord kan dus niet. Het feit dat de partijen de toepassing van een bepaalde wetsbepaling niet hebben opgeworpen, betekent niet dat zij de mogelijkheid die toe te passen bij conclusie hebben uitgesloten. ${ }^{\mathrm{I20}}$

Het akkoord moet ook duidelijk zijn. In een zaak die leidde tot een cassatiearrest van 9 mei 2008, had het hof van beroep het bestaan van een procedureakkoord over de kwalificatie 'koopovereenkomst' afgeleid uit het feit dat de eisende partij op de terechtzitting op de uitdrukkelijk vraag van de rechter of het geschil vanuit het oogpunt van een contract van aanneming diende te worden onderzocht, mondeling bevestigd had wat zij schriftelijk altijd al had verklaard, nl. dat de partijen het geschil steeds beschouwd hebben als een geschil over een koopcontract. De eisende partij had daarbij niet om toestemming gevraagd om een nieuwe conclusie te mogen nemen, zelfs niet subsidiair. Het hof van beroep stelde echter eveneens vast dat beide partijen voordien ervan uitgegaan waren dat het geschil betrekking had op een aannemingsovereenkomst en dat de eisende partij in haar proceduregeschriften nooit uitdrukkelijk het contract van aanneming als grondslag van haar vordering verworpen had. Door uit dat alles af te leiden dat de partijen bij procedureakkoord de benaming 'contract van aanneming' hadden verworpen en enkel die van koopcontract in aanmerking genomen hadden, miskende het hof van beroep zowel het beschikkingsbeginsel als het beginsel dat de rechter ertoe verplicht is de rechtsregel te bepalen die geldt voor de aan hem voorgelegde vordering en die toe te passen, aldus het Hof van Cassatie. ${ }^{121}$

Het is evenwel niet vereist dat de samenlopende wilsuitingen van de partijen om het debat tot een punt in feiten of in rechte te beperken, worden vastgelegd in een afzonderlijk instrumentum, ${ }^{122}$ laat staan dat in plechtige bewoordingen een akkoord moet worden opgesteld. ${ }^{123}$ Het volstaat dat uit de conclusies de duidelijke wil van beide partijen wordt afgeleid een welbepaalde betwisting buiten het debat te houden. ${ }^{\mathrm{I} 24}$

35. Wat 'punten in feite' betreft, lijkt de binding van procedureakkoorden absoluut te zijn. ${ }^{\text {I25 }}$

Met betrekking tot 'punten in rechte' is dat niet het geval. De ambtshalve toepassing van bepalingen van openbare orde die strijdig zijn met een procedureakkoord,

I20 Cass. 6 december 2007, C.o6.0092.N; Cass. 29 september 20II, C.Io.0349.N; Cass. 5 december 2014, RABG 2015, afl. 6, 397; concl. A. VAN INGELGEM vóór Cass. 3 I oktober 2013, C.13.0005.N.

I2I Cass. 9 mei 2008, C.o6.o64I.F.

I22 J. F. VAN DROOGHENBROECK, "La requalification judiciaire du contrat et des prétentions qui en découlent", in P. WERY en S. STIJNS (eds.), De rol van de rechter in het contract, Brugge, Die Keure, 20I4, 44 .

I23 J. VAN DONINCK, 'Ambtshalve aanvulling van rechtsgronden: een tour d'horizon' in M. PIERS, H. STORME en J. VERHELLEN (eds.), Liber Amicorum Johan Erauw, Antwerpen, 20I4, Intersentia, nr. I3.

I24 Zie voor een toepassing Cass. 23 januari 20I4, C.I2.0467.N.

I25 Het valt op dat de Franse Code de procédure civile enkel van akkoorden over rechtspunten vermeldt: 'Toutefois, [le juge] ne peut changer la dénomination ou le fondement juridique lorsque les parties, en vertu d'un accord exprès et pour les droits dont elles ont la libre disposition, l'ont lié par les qualifications et points de droit auxquels elles entendent limiter le débat.' 
kan leiden tot een uitschakeling van het procedureakkoord over de juridische aangelegenheid. ${ }^{126}$

\subsection{Aanvulling (wijziging of vervanging) van oorzaak, rechtsgrond en voorwerp}

\subsubsection{Inleiding}

36. Zoals al herhaaldelijk werd gezegd, heeft in België het Hof van Cassatie met zijn 'taakformule' een duidelijke invulling gegeven aan wat de opdracht van de rechter is in het privaatrechtelijk procesrecht, althans wat betreft het in de zaak betrekken en toepassen van rechtsregels. De rechter is met name 'gehouden het geschil te beslechten overeenkomstig de daarop van toepassing zijnde rechtsregels. Hij moet de juridische aard van de door de partijen aangevoerde feiten en handelingen onderzoeken, en mag, ongeacht de juridische omschrijuing die de partijen daaraan hebben gegeven, de door hen aangevoerde redenen ambtshalve aanvullen op voorwaarde dat hij geen betwisting opwerpt waarvan de partijen bij conclusie het bestaan hebben uitgesloten, dat hij enkel steunt op elementen die hem regelmatig zijn voorgelegd, dat hij het voorwerp van de vordering niet wijzigt en dat hij daarbij het recht van verdediging van partijen niet miskent. Hij heeft de plicht ambtshalve de rechtsmiddelen op te werpen waarvan de toepassing geboden is door de feiten die door de partijen in het bijzonder worden aangevoerd tot staving van hun eisen. Dit houdt niet in dat de rechter gehouden is alle in het licht van de vaststaande feiten van het geschil mogelijke, doch niet-aangevoerde rechtsgronden op hun toepasselijkheid te onderzoeken, doch enkel dat hij, mits eerbiediging van het recht van verdediging, de toepasselijkheid dient te onderzoeken van de niet aangevoerde rechtsgronden die zich door de feiten zoals zij in het bijzonder worden aangevoerd, onmiskenbaar aan hem opdringen'. ${ }^{127}$

Hieronder analyseer ik de verschillende elementen van die taakomschrijving, min of meer volgens de structuur van het Nederlandse preadvies.

\subsubsection{De niet-afwijkende regels voor de procedure in hoger beroep}

37. In zijn preadvies stelt Asser dat 'koerswijzigingen' in de rechtsstrijd in graad van beroep in mindere mate zijn toegestaan dan in eerste aanleg en beschrijft hij hoe de rechtsstrijd voor de Nederlandse appelrechter op dubbele wijze wordt omlijnd, enerzijds door de devolutieve werking van het hoger beroep en anderzijds door de zogeheten 'twee-conclusieregel', waarbij de appellant en de geïntimeerde hun bezwaren tegen de uitspraak in eerste aanleg moeten uiteenzetten in een memorie van grieven en een memorie van antwoord. ${ }^{\mathrm{I} 28}$

Ook in het Belgisch recht geldt het beginsel van de devolutieve werking van het hoger beroep ${ }^{\text {I29 }}$ en artikel I057 van het Gerechtelijk Wetboek vereist dat de akte van hoger beroep de uiteenzetting van de grieven vermeldt, zodat de geïntimeerde zijn conclusie

I26 Cass. 28 september 20I2, C.I2.0049.N. Zie ook nr. 6r.

I27 Cass. I4 december 20I2, C.I2.00I8.N; Cass. 5 december 20I4, RABG 20I5, afl. 6, 397.

I28 ASSER, onder 3.4.2.

I29 Artikel ro68 van het Gerechtelijk Wetboek. 
kan voorbereiden en de appelrechter in staat is de draagwijdte van het hoger beroep na te gaan. Dit vereiste belet echter niet dat de appellant in de loop van het hoger beroep bijkomende grieven kan aanvoeren tot staving van zijn oorspronkelijke vordering. ${ }^{130}$

De mogelijkheid voor de partijen om de rechtsstrijd uit te breiden of te wijzigen, enerzijds voor de eerste rechter, en anderzijds in graad van beroep, wordt in het Belgisch recht bovendien geregeld door dezelfde wettelijke bepaling en dus aan dezelfde voorwaarden onderworpen.

Artikel 807 van het Gerechtelijk Wetboek, dat overeenkomstig artikel I042 van het Gerechtelijk Wetboek ook toepasselijk is in graad van beroep, bepaalt met name dat een vordering die voor de rechter aanhangig is, kan worden uitgebreid of gewijzigd, indien de nieuwe, op tegenspraak genomen conclusies berusten op een feit of akte in de dagvaarding aangevoerd, zelfs indien hun juridische omschrijving verschillend is.

Zoals in eerste aanleg, kunnen de partijen dus ook in graad van beroep het voorwerp van hun oorspronkelijke vordering uitbreiden of wijzigen, en daaraan een nieuwe juridische omschrijving geven, op voorwaarde dat de feitelijke grondslag van de vordering niet volledig wordt gewijzigd. ${ }^{\mathrm{II}}$ De gewijzigde vordering moet weliswaar niet uitsluitend steunen op een feit of akte uit de dagvaarding, ${ }^{132}$ maar een volkomen nieuwe vordering is niet toegelaten. ${ }^{\mathrm{I} 3}$

\subsubsection{Aanvulling (of wijziging) van de rechtsgrond van de vordering}

38. In Nederland worden de mogelijkheden en beperkingen van de rechter m.b.t. de rechtsgrond van de vordering en het verweer bepaald door het samenspel van twee wettelijke bepalingen, waarvan de ene de rechter oplegt de zaak te onderzoeken en daarin te beslissen 'op de grondslag van hetgeen de partijen aan hun vordering, verzoek of verweer ten gronde hebben gelegd', ${ }^{134}$ de andere de rechter verplicht ambtshalve de rechtsgronden aan te vullen. ${ }^{135}$

In België worden die twee facetten geïntegreerd in de 'taakformule' van het Hof van Cassatie.

3.4.3.I Verplichting te beslissen op basis van de van toepassing zijnde rechtsregels

39. Volgens de recentste versie van de 'taakformule' van het Belgische Hof van Cassatie moet de rechter het geschil beslechten 'overeenkomstig de daarop van toepassing zijnde rechtsregels'. ${ }^{136}$

I30 Cass. I juni 2007, RABG 2008, 666; Cass. 8 april 20II, F.100026N - F.I00028N.

I3I K. BROECKX, Het recht op hoger beroep en het beginsel van de dubbele aanleg in het civiele geding, Antwerpen, Maklu, I995, nrs. 6r4 e.v.

I32 Cass. 8 december I980, Arr. Cass. I980-8I, 383; Cass. 6 juni 2005, Arr. Cass. 2005, nr. 317; Cass. Io november 2006, Arr. Cass. 2006, nr. 554.

I33 Zie nr. 55 .

I34 Art. 24 Rv.

I35 Art. $25 \mathrm{Rv}$.

I36 Vgl. artikel I2, eerste lid, van de France Code de procédure civile, dat luidt: 'Le juge tranche le litige conformément aux règles de droit qui lui sont applicables.' 
Door voorop te stellen dat de rechter zijn beslissing moet nemen overeenkomstig de van toepassing zijnde rechtsregels, zegt het Hof van Cassatie

I. dat de rechter niet alleen de door de partijen aangevoerde rechtsgronden in zijn beslissing moet betrekken, maar ook de rechtsgronden waarvan de partijen geen gewag maken, want de regels die 'van toepassing zijn op het geschil' zijn niet noodzakelijk door de partijen aangevoerd,

2. de rechter moet dat doen. ${ }^{\mathrm{I} 37}$

De 'taakformule' lijkt de Belgische rechter daarmee als uitgangspunt een grotere speelruimte en opdracht te geven dan die waarover de Nederlandse rechter beschikt, die rekening moet houden met de grenzen van de artikelen I49, weliswaar in essentie bewijsrechtelijk van aard en 24 van het Wetboek van Burgerlijke Rechtsvordering: terwijl de formule start met de opdracht voor de Belgische rechter naar de toepasselijke rechtsregels te speuren, beperken de genoemde artikelen van het Wetboek van Burgerlijke Rechtsvordering in beginsel de grondslag die de rechter voor zijn beslissing mag nemen respectievelijk tot 'die [...] rechten [...] die in het geding aan hem ter kennis zijn gekomen of zijn gesteld' en 'hetgeen partijen aan hun vordering, verzoek of verweer ten gronde hebben gelegd'. Het mag dan al zo zijn dat artikel 25 van het Nederlandse proceswetboek daaraan onmiddellijk weer afbreuk doet door de rechter een aanvullingsrecht toe te kennen, het startpunt is verschillend. Ook het feit dat in de artikelen I49 en 24 met 'de rechten' wellicht niet alleen of misschien zelfs niet de rechtsgrond wordt bedoeld, maar de juridische kwalificatie van de feitelijke gegevens, doet daaraan geen afbreuk: volgens de 'taakformule' moet de rechter al van meet af aan zelf actief de juridische aard van de door de partijen aangevoerde feiten en handelingen onderzoeken.

Op het beginsel dat de rechter moet beslissen door toepassing van de toepasselijke rechtsregels, laat de 'taakformule' in één adem volgen: 'Hij moet de juridische aard van de door de partijen aangevoerde feiten en handelingen onderzoeken'. ${ }^{{ }^{3} 8}$ Verder in de tekst ga ik in op de betekenis en de draagwijdte daarvan. ${ }^{139}$

\subsubsection{Verplichting tot opwerping van de rechtsgronden die zich opdringen}

\section{a. Beginsel}

40. In de derde zin van de 'taakformule' wordt gezegd dat de rechter 'de plicht [heeft] ambtshalve de rechtsmiddelen op te werpen waarvan de toepassing geboden is'.

I37 In de oorspronkelijke formulering van het arrest van I4 april 2005 was nog sprake van het iets zwakkere 'is gehouden', maar dat is ongetwijfeld te verklaren door het feit dat het om de vertaling gaat van een arrest dat werd gewezen in een Franstalige zaak, - beter vind ik - waarin sprake is van 'est tenu'. De Code de procédure civile van Frankrijk zegt het neutraler, maar daarom niet minder dwingend: 'Le juge tranche le litige conformément aux règles de droit qui lui sont applicables' (art. I2, eerste lid).

I38 Artikel I2, tweede lid, van de Franse Code de procédure civile luidt: 'Il doit donner ou restituer leur exacte qualification aux faits et actes litigieux sans s'arrêter à la dénomination que les parties en auraient proposée.'

I39 Zie nr. 45. 
De term 'rechtsmiddelen' is ongelukkig gekozen. Het gaat immers niet om de wettelijk ingestelde procedures om een rechterlijke beslissing ongedaan te maken, ${ }^{\text {I40 }}$ om de 'voies de recours', maar om 'de middelen van recht', 'les moyens de droit'. Nog beter vind ik 'rechtsgronden', met dien verstande dat dit begrip dan zowel de herkwalificatie van de feiten, de toepassing van een andere rechtsregel als het opwerpen van nieuwe juridische middelen omvat. ${ }^{\text {III }}$

Het opwerpen van de Belgische 'taakformule' is beter dan het Nederlandse aanvullen. Het gaat inderdaad om meer dan aanvullen: ook wijzigen en vervangen is mogelijk. ${ }^{\mathrm{I} 2}$

Daarop volgt in de 'taakformule' een duidelijke restrictie: de rechter moet enkel ambtshalve de rechtsmiddelen opwerpen waarvan de toepassing 'geboden is door de feiten die door de partijen in het bijzonder worden aangevoerd tot staving van hun eisen'. Dat vergt nadere toelichting.

b. Beperkingen aan de verplichting tot aanvulling (of wijziging) van de rechtsgronden

\section{$I^{\circ}$. In het bijzonder aangevoerde feiten}

4I. Het zou niet alleen onredelijk, maar ook ondoenbaar zijn van de rechter te verwachten dat hij in iedere zaak onbegrensd gaat zoeken welke mogelijke rechtsregels een implicatie zouden kunnen hebben op de beslechting van het geschil. Daarom is de op hem rustende verplichting ambtshave rechtsmiddelen op te werpen, beperkt tot die 'waarvan de toepassing geboden is door de feiten die door de partijen in het bijzonder worden aangevoerd tot staving van hun eisen'. De term 'geboden' wijst erop dat het moet gaan om een rechtsgrond die zich opdringt en dus min of meer evident is en dat op basis van wat de partijen 'in het bijzonder' hebben aangevoerd.

Dat enkel de feiten die de partijen hebben aangevoerd, in aanmerking komen, ligt voor de hand. Men kan van een civiele rechter niet verwachten dat hij zich als een onderzoeksrechter gaat opstellen.

Zoals in de 'taakformule' ook aan bod komt, mag de rechter zich uiteraard enkel steunen op feiten die hem regelmatig zijn voorgelegd.

42. Van politieke partijen, organisaties, verenigingen, enzovoort wordt tegenwoordig verwacht dat zij 'een verhaal' hebben. Nog altijd denken veel advocaten dat ook zij, om de rechter aan te spreken, 'een verhaal' van doen hebben en zij begrijpen daaronder dan uitgebreide conclusies waarin de feitelijke gegevens die van ver of van bij betrekking hebben op de zaak bladzijdenlang tot in de details worden 'verteld'. Van de rechter kan natuurlijk niet worden verwacht, en wordt dan ook

I40 DIRIX, tw. rechtsmiddel. De auteurs wijzen erop dat rechtsmiddel maar uitzonderlijk wordt gebruikt in de betekenis van 'in rechte aangevoerd argument'. De term wordt dan ook beter gereserveerd voor gebruik in zijn gangbare betekenis.

I4I B. ALLEMEERSCH, Taakverdeling in het burgerlijk proces, Antwerpen, Intersentia, 2007, nr. 69.

I42 Zie nr. 32. 
niet gevraagd, dat hij al die feiten aan de rechtsregels zou toetsten. Hij mag dat weliswaar, maar moet dat alleen doen m.b.t. de feitelijke gegevens die de partijen vermelden tot staving van hun eisen en verweer, die zij in het bijzonder aanvoeren.

Over het onderscheid tussen wat de partijen gewoon vermelden of (incidenteel, zonder meer of gewoon) aanvoeren en wat zij 'in het bijzonder aanvoeren', wordt hieronder gehandeld, bij de bespreking van de taak van de rechter m.b.t. de oorzaak van de vordering. ${ }^{143}$

\section{$2^{\circ}$. Procedureakkoorden}

43. Nog een beperking aan deverplichting totambtshalve aanvulling ofwijziging van de rechtsgronden is hierboven al aan bod gekomen, nl. waar procedureakkoorden ter sprake kwamen. ${ }^{\mathrm{I} 4}$ De rechter, zo luidt de standaardformulering van zijn taakomschrijving in civiele zaken, moet de juridische aard van de door de partijen aangevoerde feiten onderzoeken, en mag, ongeacht de juridische omschrijving die de partijen daaraan hebben gegeven, de door hen aangevoerde redenen ambtshalve aanvullen, maar dat enkel op voorwaarde 'dat hij geen betwisting opwerpt waarvan de partijen bij conclusie het bestaan hebben uitgesloten'. ${ }^{145}$ Een betere omschrijving, die meteen nog eens aantoont dat ouder niet altijd slechter betekent, komt voor in een cassatiearrest van I968: 'In burgerlijke zaken kan de rechter geen betwisting doen rijzen waarvan het met de openbare orde niet strijdig akkoord van de partijen, vervat in hun conclusies, het bestaan uitsluit'. Zij is beter omdat opwerpen niet echt het meest passende werkwoord is om te gebruiken bij betwistingen die altijd tussen de partijen en niet ten aanzien van de rechter te situeren zijn, maar vooral omdat zij ook de restrictie stelt van de openbare orde. ${ }^{\mathrm{i} 46}$

\section{$3^{\circ}$. Andere beperkingen}

44. Het verplichte actief optreden van de rechter wordt ten slotte natuurlijk ook beperkt door het verbod het voorwerp van de vordering te wijzigen ${ }^{147}$ en de verplichting tot eerbiediging van het recht van verdediging. ${ }^{\mathrm{I} 48}$

\subsubsection{Ambtshalve aanvulling (of wijziging) van de rechtsgronden en kwalificatie}

45. De eerste versie van de 'taakformule' begon ermee en in de latere versies komt het nog afzonderlijk voor volgend op de algemene opdracht te beslissen op basis van de toepasselijke rechtsregels: de rechter moet 'de juridische aard van de door de

I43 Zie nr. 5I.

I44 Cass. I7 oktober 1968, Arr.Cass. 1969, I88.

I45 Die voorwaarde is al veel ouder dan de 'taakformule', maar is daarin behouden gebleven en komt voor in alle cassatiearresten die de taak van de rechter omschrijven, te beginnen met Cass. I4 april 2005, C.03.0148.F.

I46 Zie hierover nr. 60.

I47 Zie nr. 20.

I48 Zie de nrs. 57 e.v. 
partijen aangevoerde feiten en handelingen onderzoeken'. Daarmee wordt verwezen naar de juridische kwalificatie van de feitelijke gegevens (gebeurtenissen, daden, houdingen en toestanden). De rechter moet en mag zelfs niet zomaar de kwalificatie van de partijen overnemen.

Eigenlijk is dat maar een toepassing van de al genoemde algemene regel die later terecht vooraan in de 'taakformule' is komen te staan: de rechter is gehouden het geschil te beslechten overeenkomstig de daarop van toepassing zijnde rechtsregels. Die verplichting impliceert op zich al de juridische kwalificatie van de feiten die hem zonder kwalificatie regelmatig zijn voorgelegd, eventueel ook de herkwalificatie als blijkt dat de partijen of een van hen de juridische aard daarvan verkeerd, nl. niet volgens de van toepassing zijnde rechtsregels, heeft gekwalificeerd ${ }^{149}$. De rechter is inderdaad niet gebonden door de kwalificatie die de partijen hanteren..$^{150}$

Als bv. de eiser zijn vordering enkel spreekt van een concessie van alleenverkoop, mag de rechter die tot de conclusie komt dat van dat soort overeenkomst geen sprake is, niet nalaten op grond van de door de eiser aangevoerde feiten ook te onderzoeken of geen andere verkoopovereenkomst werd gesloten, op de overwegingen dat de eiser het bestaan van dergelijke overeenkomst niet bewijst en de voornoemde feiten eerder lijken te slaan op het bewijs van een concessie van alleenverkoop. ${ }^{\text {I5 }}$

Voert een partij aan dat zij als werknemer was verbonden door een arbeidsovereenkomst, dan moet de rechter onderzoeken of er wel een contractuele arbeidsverhouding was en zo ja, of die gekenmerkt wordt door gezag van de ene partij door de andere. Voert diezelfde partij aan dat zij als werknemer werd ontslagen, dan moet de rechter die tot de conclusie komt dat tussen de partijen inderdaad een arbeidsovereenkomst bestond, oordelen of de wederpartij-werkgever wel een eenzijdige rechtshandeling heeft gesteld waardoor zij te kennen heeft gegeven dat zij aan de overeenkomst een einde wenst te maken, wat de juridische invulling is van 'ontslag'.

In een zaak waarin een cassatiearrest werd gewezen op 6 maart $2013 \cdot{ }^{152}$ In de eerste zaak vorderde de overlevende echtgenote van het slachtoffer van een verkeersongeval een uitkering onder de benaming 'préjudice d'accompagnement' die moest vergoeden dat zij tijdens haar waarschijnlijk overleven niet langer op het slachtoffer kan rekenen voor het vervullen van taken die normaal op beide echtgenoten rusten. De feitenrechter wees die vordering af op de overweging dat het Franse recht met de genoemde term iets anders bedoel, nl. de morele schade die nabestaanden lijden tijdens de traumatische aandoening tot aan het overlijden. Het Hof van Cassatie vernietigt die beslissing omdat de feitenrechter niet de werkelijke aard van de

I49 Dat is al veel langer dan de "taakformule» oud is een constante overweging in de rechtspraak van het Hof van Cassatie (zie bv. Cass. 29 november i967, Arr.Cass. I968, 460).

I50 J. VAN COMPERNOLLE en G. CLOSSET-MARCHAL, 'Examen de jurisprudence (I985-I996) Droit judiciaire privé', RCJB I997, 537.

I5I Cass. I6 maart 2006, C.04.0267.N.

I52 Weliswaar een strafzaak, maar waarin uitspraak wordt gedaan over een burgerlijke vordering, zij het met toepassing van artikel $\mathrm{I}_{3} 82$ van de Franse Code civil: Cass. 6 maart 20I3, P.I2.I596.F. 
schade heeft vastgesteld en niet heeft onderzocht of die schade als materiële schade vervoerbaar kon zijn.

In een zaak waarin het Hof van Cassatie op 27 september $2013^{153}$ uitspraak deed, vorderde de verwerende partij in cassatie 2.500 euro schadevergoeding wegens tergend en roekeloos beroep en 900 euro rechtsplegingsvergoeding in hoger beroep. Het hof van beroep besliste dat het aantal en de aard van de procedurehandelingen die de advocaat van de verwerende partij had moeten stellen, verantwoordt dat de rechtsplegingsvergoeding wordt vastgesteld op het maximumbedrag van 2.000 euro. De feitenrechter geeft aldus aan de door de verwerende partij in cassatie aangevoerde feiten een nieuwe juridische omschrijving zonder een geschil op te werpen waarvan de partijen het bestaan uitsloten, aldus het Hof van Cassatie.

46. Terloops en ten slotte zij er nog aan herinnerd dat de rechtsgrond van de vordering bepalend is voor de bevoegdheid van de rechter. Volgens een vaste cassatierechtspraak van het Hof van Cassatie wordt de volstrekte bevoegdheid van de rechter bepaald naar het onderwerp (beter: het voorwerp) van de vordering en moet zij worden beoordeeld, niet naar het door de feitenrechter vast te stellen werkelijk onderwerp (lees: voorwerp) van het geschil, maar wel 'naar de vordering zoals zij door de eiser is voorgedragen'. ${ }^{154}$

Terecht werd opgemerkt dat die visie niet spoort met de taak die het Hof voor de rechter weglegt: de rechtsregels toepassen op de feiten. ${ }^{155}$ Inderdaad, wanneer een partij die in een contractuele arbeidsverhouding staat ten overstaan van een wederpartij, aanvoert werknemer te zijn omdat de arbeidsverhouding een arbeidsovereenkomst is, moet de arbeidsrechtbank op grond van de feiten oordelen of er bevoegdheid tot gezagsuitoefening door de wederpartij is. Is dat niet het geval, dan herkwalificeert hij en verandert hij de hoedanigheid van de eiser van werknemer in die zin van zelfstandige en de rechtsgrond van diens vordering van een arbeidsovereenkomst in een aannemingsovereenkomst of overeenkomst voor het verrichten van diensten. Als de rechter bevoegd is de feiten te kwalificeren om de grond van de zaak te beoordelen, waarom zou hij zich dan niet op grond van diezelfde kwalificatie bevoegd of onbevoegd mogen verklaren?

\subsubsection{Aanvulling (of wijziging) van de oorzaak van de vordering (de feiten waarop zij steunt)}

\subsubsection{Beginsel}

47. Wie de tekst van dit onderdeel van dit Belgisch preadvies wil toetsen aan het Nederlandse, moet voor dit laatste terecht bij het randnummer 3.3. met het

I53 Cass. 27 september 2013, C.I2.038I.F.

I54 O.a. Cass. I9 december I985, RW I986-87, 280, concl. E. KINGS; Cass. 5 november 20I2, JT 20I3, 320.

I55 J. VAN DROOGHENBROECK «La requalification judiciaire du contrat et des prétentions qui en découlent» in P. WERY, S. STIJNS (eds.), De rol van de rechter in het contract, Brugge, Die Keure, 20I4, nr. 70 e. v. 
opschrift 'De grondslag van de beslissing - Art $24 \mathrm{Rv}$ "De rechter onderzoekt en beslist de zaak op de grondslag van hetgeen partijen aan hun vordering, verzoek of verweer ten gronde hebben gelegd, tenzij uit de wet anders voortvloeit"'. Die begrenzing van de rechtsstrijd moet worden gecombineerd met de bewijsrechtelijke bepaling van artikel I49 van het Wetboek van Burgerlijke Rechtsvordering, die aangeeft op welke 'feiten of rechten' de Nederlandse rechter zijn beslissing mag steunen en die Asser vooraf behandelt onder 3·3.2.2 van zijn preadvies, maar ook onder het kopje 3·3.2 'De rechter mag niet treden buiten de rechtsstrijd'. Zoals uit de termen 'grondslag' en 'feiten en rechten' blijkt en Asser toelicht in het Nederlandse preadvies, wordt in Nederland geen scherp onderscheid gemaakt tussen wat in België de oorzaak (de feiten) en de rechtsgrond (de rechten) van de vordering wordt genoemd, wat m.a.w. de feitelijke en de juridische 'grondslag' van de vordering is. ${ }^{56}$

In België gebeurt dat meer en dat werd nog scherper gesteld sinds de intrede van de 'taakformule' van het Hof van Cassatie. Wel wordt, zoals boven al herhaaldelijk is tot uiting gekomen, de term 'oorzaak' van de vordering de laatste jaren minder gebruikt $\mathrm{t}^{157}$ en hij komt ook niet voor in de 'taakformule'. Men heeft het eerder over de 'door de partijen aangevoerde feiten en handelingen'. Mijn voorkeur gaat uit naar het behoud van de term 'oorzaak' omdat die gebalder is dan 'aangevoerde feiten en handelingen', uitdrukking die overigens erg onvolledig is: ook gebeurtenissen, houdingen, onthoudingen en situaties komen in aanmerking, maar zijn niet altijd echt feiten of handelingen. Met 'oorzaak' bedoel ik dan ook 'feitelijke gegevens'. De 'oorzaak' is het rechtsfeit dat het geschil heeft uitgelokt. ${ }^{158}$

48. De 'taakformule' van het Hof van Cassatie bepaalt over de taak van de rechter ten aanzien van de feitelijke gegevens twee zaken:

- 'hij moet de juridische aard van de door de partijen aangevoerde feiten en handelingen onderzoeken' en

- hij 'heeft de plicht ambtshalve de rechtsmiddelen op te werpen waarvan de toepassing geboden is door de feiten die door de partijen in het bijzonder worden aangevoerd tot staving van hun eisen'.

De formule legt de rechter dus op alle aangevoerde feitelijke gegevens aan een juridisch onderzoek te onderwerpen. Op de in het bijzonder tot staving van eis of verweer aangevoerde feitelijke gegevens moet hij bovendien ambtshalve het recht toepassen dat daarop van toepassing is, m.a.w. ook als het gaat om rechtsregels waarvan de partijen geen gewag hebben gemaakt.

I56 ASSER, onder $3 \cdot 3 \cdot 2 \cdot 3$, derde alinea.

I57 Dixit A. HENKES in zijn conclusie vóór Cass. 28 mei 2009, Arr.Cass. 2009, afl. 5, I48I; anders: J.F. VAN DROOGHENBROECK, "Chronique de l'office du juge», JLMB 20I3, afl. 25, I307-I320, I308, volgens wie de rechtspraak dat woord wel blijft gebruiken. Men treft het inderdaad soms nog in vrij recente arresten aan zelfs van na het ontstaan van de 'taakformule', bv. in Cass. I5 februari 2008, C.o6.oI84.F.

I58 DIRIX, tw. vordering. 


\subsubsection{Incidenteel en in het bijzonder aangevoerde feitelijke gegevens}

49. In de eerste versie van de 'taakformule', in een cassatiearrest van I4 april 2005, wordt gewag gemaakt van de feiten die de partijen 'in het bijzonder' hebben aangevoerd. In latere versies, zoals bv. in de door Van Drooghenbroeck als perfect genoemde versie van een arrest van 2 april 20I0, ${ }^{159}$ komen de woorden 'in het bijzonder' niet meer voor. Dat is mogelijk toe te schrijven aan het feit dat in de term aanvoeren al een zekere gerichtheid begrepen is die verder gaat dan een terloopse vermelding. ${ }^{160}$ Maar in de formulering van een cassatiearrest van 14 december 20I2, die ik beter vind omdat zij vollediger is, duikt 'in het bijzonder' terug op. ${ }^{\mathrm{I} 6 \mathrm{I}}$ De vereiste van gerichtheid wordt ook nog onderstreept doordat wordt gezegd dat de rechter enkel ambtshalve het recht moet toepassen op de feiten die de partijen hebben aangevoerd 'tot staving van hun eisen', waaronder ongetwijfeld ook het verweer mag worden begrepen.

Op de gericht aangevoerde feitelijke gegevens moet de rechter, zelfs ambtshalve, de toepasselijke rechtsregels toepassen. Het gaat om de feitelijke gegevens die onlosmakelijk deel uitmaken van de gevolgde door de eiser of de verweerder redenering en expliciet of impliciet worden aangewezen als onontbeerlijk. Zij vormen het 'voetstuk' van een middel of de middelen. ${ }^{162}$ De gedachte spreekt aan dat het gaat om feiten waaruit rechtsgevolgen werden afgeleid. ${ }^{16_{3}}$

50. Daarnaast zijn er feitelijke gegevens die een partij gewoon vermeldt, zonder die te betrekken bij de ontwikkeling van het middel. Dergelijke gegevens worden aangehaald of vermeld. Men kan die vermelding ook aanvoering noemen, maar dan gebruikt men die term met veronachtzaming van de nuance van gerichtheid die daarin steekt. Sommigen spreken van 'incidenteel aanvoeren', ${ }^{164}$ maar eigenlijk is dat een constructie van het kaliber van 'onvrijwillig beogen' of 'opzettelijk vergeten'. In het Frans onderscheidt men 'faits spécialement invoqués' van 'faits adventices', te vertalen als (in het bijzonder) ${ }^{165}$ aangevoerde feiten en terloopse feiten.

Bij die laatste categorie aanleunend, maar toch nog enigszins verschillend, zijn de feitelijke gegevens die door de partijen zelf niet worden vermeld in hun conclusies en pleidooien, maar door de rechter worden vastgesteld op basis van de overtuigingsstukken die de partijen hem voorleggen.

I59 Zie nr. 5 .

I6o Zie voetnoot 12 .

I6I Zie nr. 5.

I62 J. VAN DROOGHENBROECK, "La requalification judiciaire du contrat et des prétentions qui en découlent», in P. WERY en S. STIJNS (eds.), De rol van de rechter in het contract, Brugge, Die Keure, 20I4, 2I. Hiervoor gebruikt de auteur het woord invoquer, letterlijk: inroepen, wat ik voorbehoud voor juridische middelen: zie nr. 4 .

I63 J. VAN DONINCK, 'Ambtshalve aanvulling van rechtsgronden: een tour d'horizon' in M. PIERS, H. STORME en J. VERHELLEN (eds.), Liber Amicorum Johan Erauw, Antwerpen, 20I4, Intersentia, nr. 5.

I64 Van Drooghenbroeck spreekt van een feit waarvan enkel het bestaan wordt gesignaleerd, dat enkel toevallig in het debat voorkomt (J.F. VAN DROOGHENBROECK, «La requalification judiciaire du contrat et des prétentions qui en découlent», in P. WERY en S. STIJNS (eds.), De rol van de rechter in het contract, Brugge, Die Keure, 20I4, 2I). Hij gebruikt daarvoor het woord alléguer, dat afkomstig is van ad legare en dus eigenlijk verwijzen betekent, aldus de Dictionnaire le Littré.

I65 In de Nederlands vertaling van et Frans gewezen «perfecte arrest van 2 april 2oro wordt «spécialement invoqués» vertaald als «aangevoerd» zonder meer. Zie ook voetnoot $\mathrm{I} 2$. 
M.b.t. de 'in het bijzonder aangevoerde' feitelijke gegevens moet de rechter, zoals gezegd, de toepasselijke rechtsregels opsporen en toepassen. M.b.t. de 'incidenteel aangevoerde' feitelijke gegevens moet hij dat niet. Maar hij mag het, aangezien hij, zo blijkt uit de aanhef van de 'taakformule' alle door de partijen aangevoerde gegevens van het geschil moet onderzoeken met het oog op de toepassing daarop van de rechtsregels in zijn uiteindelijke beslissing. ${ }^{66}$ Daardoor schendt hij niet het beschikkingsbeginsel. Zolang de rechter zich steunt op door de partijen naar voren gebrachte feiten, schendt hij het beschikkingsbeginsel in dit opzicht niet. ${ }^{167}$

In een arrest van 5 december 2013 overweegt het Hof van Cassatie dat met de feiten die door de partijen in het bijzonder worden aangevoerd tot staving van hun eisen, moeten worden gelijkgesteld, de feiten die de rechter zelf naar voren heeft gebracht uit 'de elementen' die hem regelmatig door de partijen werden voorgelegd. ${ }^{168}$ Dat is logisch. Als een rechter niet van plan is rechtsgevolgen vast te knopen aan incidenteel, terloops of toevallig door de partijen vermelde feiten, moet hij die maar niet naar voren brengen. Hij is daartoe immers niet verplicht. Doet hij dat toch, dan is hij gehouden daarop de rechtsregels toe te passen: wie A zegt, moet B zeggen.

5I. De vraag rijst welke gegevens de rechter mag beschouwen als zijnde door de partijen 'aangevoerd' in het algemeen en welke daarvan als door hen 'in het bijzonder aangevoerd'. Als men oorzaak omschrijft als de juridisch relevante gebeurtenis, handeling, houding of toestand, samengevat: de feitelijke gegevens die tot het geschil aanleiding hebben gegeven, dan geeft men de indruk dat het enkel gaat om de feitelijke gegevens waarop een partij zich heeft beroepen, die zij doelgericht heeft vermeld en naar voren geschoven, die zij m.a.w. heeft aangevoerd in de genuanceerde betekenis van dit woord. ${ }^{169}$ Dat is trouwens ook de term die de 'taakformule' gebruikt: de rechter moet de juridische aard van de door de partijen 'aangevoerde' feiten en handelingen onderzoeken.

Toch ben ik ervan overtuigd dat men aanvoeren hier moet lezen in de ruimste betekenis waarin dit woord kan worden gebruikt en dus ook in de zin van vermelden en zelfs van in het dossier voorkomen. In de uitgebreidere, door mij geprefereerde versie van de 'taakformule' wordt niet voor niets gesproken van 'de feiten die door de partijen in het bijzonder worden aangevoerd tot staving van hun eisen' als men het heeft over wat de rechter moet doen met de feitelijke gegevens. De formule makkt dus zelf

I66 In artikel 7, tweede lid, van de Franse Code de procédure civile wordt dat uitdrukkelijk gezegd: 'Parmi les éléments du débat, le juge peut prendre en considération même les faits que les parties n'auraient pas spécialement invoqués au soutien de leurs prétentions'.

I67 Cass. I5 februari 2008, C.o6.or84.F.

I68 Cass. 5 december 2013, C.I2.0599.N: de eiser stelde een vordering in op basis van vermogensvermeerdering zonder oorzaak. Dat is een subsidiaire vordering, in die zin dat zij enkel kan slagen bij ontstentenis van een andere rechtsgrond. De feitenrechter kwam tot de vaststelling dat de handelwijze van de verweerder een flagrante fout is in de zin van artikel $\mathrm{I}_{3} 82$ van het Burgerlijk Wetboek, maar wees de vordering van de verweerder af omwille van haar subsidiaire aard. Dat mag niet, zegt het Hof van Cassatie: de feitenrechter had ambtshalve de mogelijke toepassing van de voornoemde wetsbepaling moeten opwerpen.

I69 Zie over de betekenis van aanvoeren, nr. 4 . 
een onderscheid tussen 'gewoon' aanvoeren - beter zou zijn: vermelden - en 'in het bijzonder aanvoeren'.

Zoals gezegd, zou ik trouwens, hoewel dat mij als advocaat frustreert, als academicus nog een stap verder gaan en ook m.b.t. feitelijke gegevens waarvan de partijen geen gewag maken in hun conclusies of pleidooien, hetzelfde standpunt innemen als t.a.v. 'gewoon' aangevoerde feitelijke gegevens. Ik word daartoe gebracht door de bedenking dat het niet past bij de figuur van de actieve rechter, van wie wordt verwacht dat hij ervoor zorgt dat werkelijk recht geschiedt, dat hij zou moeten doen alsof zijn neus bloedt als hij in het dossier op een feitelijk gegeven stoot dat volgens hem (mee) bepalend is voor wat zijn beslissing in rechte moet zijn, ook al hebben de partijen daarvan geen gewag gemaakt. Men kan dat bij de zaak betrekken van dergelijke feitelijke gegevens ook bezwaarlijk op zich een schending van het recht van verdediging noemen. Vooreerst is het zo dat, als de partijen vinden dat feitelijke gegevens uit het geding moeten worden geweerd, zij ofwel de stukken waaruit die gegevens blijken, maar niet moeten overleggen of dat zij, als zij dergelijke stukken toch moeten voorleggen omwille van andere zaken die zij bevatten of aantonen, maar een processuele overeenkomst moeten sluiten om die uit de debatten te weren. ${ }^{170}$ Bovendien lijkt het mij evident dat de rechter die met een feitelijk gegeven naar voren komt dat aan de hierboven beschreven kenmerken voldoet, dat gegeven aan de tegenspraak van de partijen moet onderwerpen. ${ }^{\text {I7I }}$

Ik ben dus van oordeel dat niet alleen alle feitelijke gegevens die de partijen 'in het bijzonder' aanvoeren in hun conclusies en pleidooien, maar ook al die welke zij terloops, incidenteel toevallig vermelden en die welke zich in het dossier bevinden, moeten worden beschouwd als zijnde door de partijen aangevoerd (de twee laatste categorieën: 'gewoon' aangevoerd) in de zin van de 'taakformule'. ${ }^{172} \mathrm{Ik}$ ben m.a.w. voorstander van toepassing van de equivalentieleer op de feitelijke gegevens: elk vermeld gegeven behoort tot de categorieën aangevoerde feiten.

Of dat 'juist' is, is een andere vraag. In ieder geval lijkt de Belgische rechter ruimere mogelijkheden te hebben dan Nederlandse die op grond van artikel 24 van het Wetboek van Burgerlijke Rechtsvordering gebonden is door de 'grondslag van hetgeen partijen aan hun vordering, verzoek of verweer ten gronde hebben gelegd'. Maar dat moet worden genuanceerd, want (I) de Hoge Raad laat de rechter veel ruimte om de feitelijke grondslag voor de ambtshalve rechtstoepassing aanwezig te achten ${ }^{173}$ en (2) de Nederlandse rechter kan (of moet) de partijen blijkbaar uitnodigen de grondslag van hun vordering te wijzigen. ${ }^{174}$

\footnotetext{
I70 Zie nr. 34 .

I7I Zie nr. 58.

I72 A. HENKES verdedigt dezelfde opvatting in zijn conclusie vóór Cass. 28 mei 2009, Arr.Cass. 2009, afl. 5 , I480.

I73 ASSER, onder 3.4.4, laatste alinea.

I74 ASSER, onder 3.I, laatste alinea, 3.4.5.I, eerste alinea, en 3.4.6, laatste alinea.
} 
52. Als men aanneemt dat de rechter op incidenteel toevallig of terloops vermelde feitelijke gegevens ambtshalve het recht mag toepassen, krijgt hij wel een verregaande 'inspraak' m.b.t. de feitelijke grondslag van vordering en verweer. Twee voorbeelden kunnen dat aantonen. Beide hebben betrekking op feitelijke gegevens die niet 'in het bijzonder' werden aangevoerd tot staving van eis of verweer. In het eerste voorbeeld blijken zij uit de neergelegde stukken, in het tweede uit gegevens die vermeld worden in de conclusies, telkens zonder daaraan rechtsgevolgen te knopen.

Eerste voorbeeld. Veronderstellen wij dat een werknemer van zijn werkgever achterstallig loon vordert. De werkgever verweert zich door aan te voeren dat hij, weliswaar zonder een kwijting te vragen, het loon in de hand heeft betaald. Hij legt een uitvoerige briefwisseling met de werknemer daarover neer. Bij zijn lectuur van de stukken stelt de rechter vast dat de werknemer in een van die brieven in onvoorwaardelijke termen afstand heeft gedaan van zijn loonaanspraken vóór een bepaalde datum. De (advocaat van de) werkgever heeft dat over het hoofd gezien en heeft de brief waarin de afstand voorkomt, dus zeker niet 'in het bijzonder' aangevoerd 'tot staving van zijn eis'. De (advocaat van de) werknemer zwijgt daarover vanzelfsprekend in alle talen. Een mogelijke betwisting over de afstand hebben zij door hun louter stilzwijgen uitgesloten. Als men aanneemt, zoals ik doe, dat de (advocaat van de) werkgever de brief, door hem op te nemen in de stukken die hij neerlegt, 'incidenteel' of 'gewoon' heeft aangevoerd, zelfs al heeft hij daarnaar niet verwezen in zijn conclusies of pleidooi, heeft de rechter de keuze tussen doen alsof hij, zoals de werkgever, de afstand in de brief niet heeft gemerkt en mag hij de vordering van de werknemer ondanks de door hem vastgestelde afstand volledig inwilligen, dan wel ambtshalve opwerpen dat hij meent dat een brief die in het dossier steekt, een afstand zou kunnen bevatten die de vordering van de werknemer deels ongegrond zou maken en, met respect voor het recht van de verdediging, de partijen uitnodigingen daarover een standpunt in te nemen. ${ }^{175}$ In geen van beide gevallen - in het eerste uiteraard niet, maar ook in het tweede niet - schendt hij het beschikkingsbeginsel: hij wijzigt de 'oorzaak' van de vordering niet. Hij past het recht toe op 'de zaak'.

Tweede voorbeeld. Veronderstellen wij dat een werknemer de werkgever die hem op staande voet, maar zonder dringende reden heeft ontslagen, voor de rechter daagt (sleept pleegt men tegenwoordig in de media te zeggen). In de akte die het geding inleidt, schetst de (advocaat van de) werknemer kort de beroepsloopbaan van de werknemer en daarbij vermeldt hij dat deze laatste voordien bij een dochtervennootschap van de werkgever was tewerkgesteld. De (advocaat van de) werknemer vordert een opzeggingsvergoeding berekend met inachtneming van de anciënniteit opgebouwd bij de moedervennootschap. Tot staving van zijn eis voert de (advocaat van de) werknemer enkel (in het bijzonder) aan dat de werknemer sinds een bepaalde datum met de (laatste) werkgever verbonden was door een arbeidsover-

I75 Sommige rechters kiezen voor een tussenoplossing en scheppen er (in het gegeven voorbeeld) genoegen in de (advocaat van de) verweerder een veeg uit de pan te geven door in het vonnis te vermelden dat ze de afstand wel hebben opgemerkt, maar daarmee geen rekening hebben gehouden aangezien de verwerende partij blijkbaar ervan heeft afgezien zich op die afstand te beroepen. 
eenkomst en dat aan die overeenkomst een einde werd gemaakt door de werkgever zonder inachtneming van een opzeggingstermijn. Bij de bepaling van de opzeggingstermijn die de werkgever had moeten in acht nemen, is de rechter niet verplicht rekening te houden met de anciënniteit die de werknemer al had opgebouwd bij de dochtervennootschap van zijn werkgever, hoewel die juridisch ook in aanmerking komt: anciënniteit is een ononderbroken tewerkstelling bij dezelfde economische entiteit. Maar de rechter mag dat wel ambtshalve doen en hij schendt daardoor niet het beschikkingsbeginsel. Als het totale bedrag van de geldsommen die de werknemer vordert op grond van de beëindiging van de arbeidsovereenkomst niet lager is dan de opzeggingsvergoeding die met inaanmerkingneming van de anciënniteit bij de dochtervennootschap op grond van de wet verschuldigd is (zo niet zou ultra petita geoordeeld worden), mag de rechter die opzeggingsvergoeding, die meer bedraagt dan de opzeggingsvergoeding die de werknemer vorderde, toekennen. Het excedent wordt dan bv. 'gefinancierd' door (een deel van) de uitwinningsvergoeding die de werknemer eveneens in de vorm van een geldsom vorderde, maar die de rechter als zodanig niet toekende omdat de werknemer geen handelsvertegenwoordiger was. Wat de rechter m.a.w. als geldsom toekent, was ook als geldsom gevorderd. ${ }^{176}$

53. Op grond van de cassatierechtspraak valt moeilijk uit te maken of het Hof dezelfde, verstrekkende, zienswijze wel is toegedaan, zoals blijkt uit de twee volgende arresten.

In de zaak die leidde tot een arrest van het Hof van Cassatie van I8 november 2004, ${ }^{\mathrm{I} 7}$ vorderde een partij bij een concessieovereenkomst - uit het gepubliceerde uittreksel van het arrest blijkt niet duidelijk welk van beide partijen - een vergoeding op grond van de beëindiging van de overeenkomst die zij had gesloten met de verwerende partij. Die vergoeding moest dienen tot herstel van haar reputatie die was geschonden door de omstandigheden waarin de verwerende partij eenzijdig de overeenkomst had beëindigd, en meer bepaald door de onmiddellijke uitwerking die zij eraan heeft gegeven. Het hof van beroep willigde de vordering gedeeltelijk in, maar op het motief dat de houding van de verwerende partij nadeel had berokkend aan de eisende partij door niet mee te werken om de ware toedracht te verduidelijken en nadien te weigeren de impasse te doorbreken. Het Hof van Cassatie vernietigde dat arrest omdat het steunt op feiten die niet door de partijen waren aangevoerd en aldus de oorzaak van de vordering wijzigde en het beschikkingsbeginsel miskende. Ik neem nochtans aan - het valt niet op te maken uit het gepubliceerde uittreksel dat het hof van beroep zich wel steunde op feiten die bleken uit het dossier om te beslissen zoals het heeft gedaan. Het verving de door de eisende partij als grondslag van haar vordering aangevoerde feiten door andere feiten.

Tot een andere conclusie komt het Hof van Cassatie in een arrest van I2 oktober 2006. ${ }^{178}$ Vier aanbesteders vorderden vergoeding van de schade die de gebreken

I76 Vergelijk met het cassatiearrest van 27 september 2013, vermeld in nr. I7.

177 Cass. I8 november 2004, C.04.0062.F.

I78 Cass. I2 oktober 2006, Arr. Cass. 2006, I988. 
aan hun bouwwerk opleveren. De aannemer wierp tegen dat zij vrijwillig hadden afgezien van de bijstand van een architect en zodoende gedeeltelijk zelf aansprakelijk waren voor de schade waarvoor zij vergoeding vorderen. De aanbesteders antwoordden daarop dat de aannemer hun een bevriend architect had opgedrongen, wiens heel beperkt optreden slechts een voorwendsel was om te voldoen aan de stedenbouwkundige voorschriften en dat de aannemer, indien hij vond dat de aanwezigheid van een door hen gekozen architect onontbeerlijk was, hun dat had moeten melden en desnoods het werk had moeten stilleggen. In zijn arrest onderzocht het hof van beroep of de bouwheren wel verplicht waren een beroep te doen op een architect en of het optreden van een architect de schade waarover zij klaagden, had kunnen vermijden. Het hof beantwoordde beide vragen ontkennend en besliste dat de aannemer met kennis van zaken en zonder voorbehoud aanvaard heeft het werk uit te voeren zonder dat de bouwheren door een architect bijgestaan werden. Het wees elke aansprakelijkheid van de aanbesteders af. In het cassatiemiddel voerde de aannemer aan dat geen van de verweermiddelen waarvan sprake in het arrest van het hof van beroep door de bouwheren was opgeworpen. Het hof van beroep, aldus nog het cassatiemiddel, wierp derhalve ambtshalve een geschil op en schond bijgevolg het beschikkingsbeginsel. Neen, zo beslist het Hof van Cassatie, door te steunen op feiten die regelmatig aan de beoordeling van het hof van beroep zijn voorgelegd, beperkte het hof van beroep zich ertoe de door de partijen aangevoerde redenen te vervangen zonder enig geschil op te werpen waarvan zij het bestaan hadden uitgesloten.

54. Als wij de term 'oorzaak van de vordering' in de zin van - in essentie en meestal zelfs uitsluitend - de feitelijke grondslag daarvan blijven aanhouden en aan het woord 'grondslag' de ruime invulling geven die ik voorsta, ${ }^{179}$ dan is het duidelijk dat de rechter de oorzaak niet uit eigen beweging kan aanvullen. Zeggen dat de rechter de oorzaak niet mag wijzigen, enerzijds, en dat hij zijn beslissing alleen mag steunen op feiten die hem regelmatig ter beoordeling zijn voorgelegd, anderzijds, is hetzelfde. ${ }^{\mathrm{I} 80}$ De feitelijke contouren van een geding worden uitsluitend bepaald door de partijen. De rechter kan daarin alleen onrechtstreeks ingrijpen langs de weg en binnen de grenzen van de onderzoeksmiddelen die de wet hem ter beschikking stelt, zoals overlegging van stukken, getuigenverhoor, persoonlijke verschijning, deskundigenonderzoek en plaatsopneming, die het Gerechtelijk Wetboek samenbrengt in een hoofdstuk met het opschrift 'Bewijs' ${ }^{18 \mathrm{I}}$ Maar hij moet daarbij altijd vertrekken van een feit dat door de partijen is vermeld.

Dat komt tot uiting in de 'taakformule' van het Hof van Cassatie, die weergeeft wat van een rechter wordt verwacht in een privaatrechtelijk geding. Daarin is sprake van 'de door de partijen aangevoerde feiten en handelingen' en van de beperking dat hij 'enkel steunt op elementen die hem regelmatig zijn voorgelegd', dat laatste uiteraard door de partijen. Maar in het Nederlandse recht is de partijenautonomie veel groter en in ieder geval duidelijk afgelijnd: de feiten die niet door een partij 'ten grondslag

I79 Zie nr. 5I.

I80 Concl. A. HENKES vóór Cass. 28 mei 2009, Arr.Cass. 2009, afl. 5, I48I.

I8I Hoofdstuk VIII van Titel III van boek II van het Gerechtelijk Wetboek. 
zijn gelegd' aan de vordering of het verweer (en overigens ook de rechtsgrond!) waarmee de rechter de vordering of het verweer wil uitbreiden, moeten, om in de rechtsstrijd betrokken te kunnen worden, door die partij worden overgenomen. ${ }^{182}$

55. Louter voor de volledigheid breng ik hier nog eens even in herinnering dat de partijen zelf in de loop van het geding, zelfs in een andere instantie, natuurlijk nieuwe feiten kunnen aanvoeren ter staving van hun standpunt. Zij kunnen hun oorspronkelijke vordering bovendien uitbreiden of wijzigen voor zover de uitgebreide of gewijzigde vordering berust op een feit of akte in de dagvaarding aangevoerd. ${ }^{183}$

De rechter van zijn kant kan de vordering ook inwilligen op grond van andere feiten dan die in de dagvaarding vermeld, bijvoorbeeld feiten die hij terugvindt in de overtuigingsstukken. Hij lijkt op dit punt dan ook over een grotere vrijheid lijkt te beschikken dan de partijen, zij het weliswaar niet om de vordering uit te breiden, dan toch ook om ze te wijzigen, bv. door het voorwerp anders te kwalificeren.

\subsubsection{Aanvulling (of wijziging) van het voorwerp van de vordering}

56. Hierboven werd al meermaals toegelicht wat de draagwijdte is van het beschikkingsbeginsel. ${ }^{184}$ Het impliceert dat de rechter het voorwerp van de vordering niet mag wijzigen. Ik geef twee voorbeelden uit de cassatierechtspraak waarin het Hof oordeelde dat de feitenrechter dat ten onrechte wel had gedaan, in het eerste geval m.i. zelf ten onrechte.

Een partij vorderde de nietigverklaring van een verkoopovereenkomst omwille van het wilsgebrek bedrog. De feitenrechter sprak echter de ontbinding van de koop uit wegens een contractuele fout. Daardoor wijzigde hij volgens het Hof van Cassatie het voorwerp van de vordering, zodat hij het beschikkingsbeginsel schond. ${ }^{185}$ Het is onwaarschijnlijk dat het Hof nu nog in dezelfde zin zou oordelen, aangezien het thans aanneemt dat het voorwerp van de vordering een feitelijk iets is. ${ }^{186}$ In die zaak wou de eiser immers niets anders dan de overeenkomst weg. Het economisch, moreel en sociaal voordeel dat hij nastreefde bestond in de vernietiging van de rechtsverhouding die de verkoop meebracht. Ik merk terloops op dat de feitenrechter volgens het Hof ook de oorzaak van de vordering wijzigde en dat het Hof mede om die reden zijn uitspraak vernietigt wegens schending van het beschikkingsbeginsel. In het licht van de nieuwe taakomschrijving van de rechter zou het Hof ook dat laatste thans allicht niet meer zo bekijken. ${ }^{\mathrm{I}}{ }^{87}$

Tweede voorbeeld. Een partij vordert de uitvoering in natura van een overeenkomst en de tegenpartij voert niet aan dat een uitvoering in natura een misbruik van recht

I82 ASSER, onder 3.3.2.3, eerste alinea, en 3.4.5.I, derde laatste en voorlaatste alinea.

I83 Artikel 807 van het Gerechtelijk Wetboek. Zie ook nr. 37.

I84 Zie o.a. de nrs. 20 e.v.

I85 Cass. 8 februari 200I, C.00.0222.F.

I86 Zie nr. I7.

I87 Het arrest wordt op die twee punten terecht bekritiseerd door J. F. VAN DROOGHENBROECK, «La requalification judiciaire du contrat et des prétentions qui en découlent», in P. WERY en S. STIJNS (eds.), De rol van de rechter in het contract, Brugge, Die Keure, 20I4, 59. 
zou uitmaken. In dat geval mag de rechter niet de ontbinding van de overeenkomst bevelen met schadevergoeding op grond dat een uitvoering in natura een misbruik van recht zou uitmaken. ${ }^{\text {188 }}$

Gaat men ervan uit dat het Hof van Cassatie het voorwerp van de vordering nog altijd niet louter feitelijk invult, dan is er een subtiel verschil in de rol van de rechter op het vlak van de 'herkwalificatie' van de vordering, met name tussen een onwettige wijziging van het voorwerp en een toegelaten herkwalificatie wanneer de door de partijen gegeven kwalificatie niet overeenstemt met wat de eisende partij werkelijk beoogt. ${ }^{189}$

\subsubsection{Nooit te vergeten: het recht van verdediging}

57. Het algemeen beginsel van het recht van verdediging stelt fundamentele beperkingen aan de mogelijkheden of verplichtingen van de rechter ambtshalve op te treden. Terecht heeft het Hof van Cassatie in de verschillende versies van zijn 'taakformule' altijd de eerbiediging van het recht van verdediging als een voorwaarde gesteld voor rechterlijk activisme. En artikel 774, tweede lid, van het Gerechtelijk Wetboek bepaalt dat de rechter de heropening van het debat moet bevelen alvorens de vordering geheel of gedeeltelijk af te wijzen op grond van een exceptie die de partijen voor hem niet hadden ingeroepen.

Naar de smaak van een advocaat komt het beginsel van het recht van verdediging, wat in Nederland in deze context het beginsel van hoor en wederhoor wordt genoemd, te terloops, zij het op verschillende plaatsen, aan bod in het preadvies van Asser, die het nochtans terecht de eerste waarborg noemt voor een eerlijk proces. ${ }^{190}$ Dat is mee het gevolg van het feit dat de Nederlandse rechter op grond van de bepalingen van het Wetboek van Burgerlijke Rechtsvordering toch wel over wat minder speelruimte lijkt te beschikken dan de Belgische op grond van de 'taakformule'. Hoe dan ook, in België is het recht van verdediging van doorslaggevend belang en wordt het terecht altijd prominent in de 'taakformule' vermeld.

Zelf ben ik een fan van de duidelijke formulering van artikel i6 van de Franse Code de procédure civile:

\footnotetext{
'Le juge doit, en toutes circonstances, faire observer et observer lui-même le principe de la contradiction. Il ne peut retenir, dans sa décision, les moyens, les explications et les documents invoqués ou produits par les parties que si celles-ci ont été à même d'en débattre contradictoirement.

Il ne peut fonder sa décision sur les moyens de droit qu'il a relevés d'office sans avoir au préalable invité les parties à présenter leurs observations.'
}

I88 Cass. 9 mei 2003, C.00.0203.N.

I89 M. VAN QUICKENBORNE, Feit en recht of de rechter en de procespartijen, Brussel, H. Swinnen, I987, Ioo. I9o Onder I.2, eerste alinea. 


\section{Dat zegt alles.}

De hierboven geciteerde bepaling van het Franse wetboek van burgerlijk procesrecht erkent dat het recht op verdediging in beginsel aan de orde is telkens een rechter iets doet wat niet het voorwerp is geweest van tegenspraak. Alleen het zeldzame geval waarin de partijen enkel feiten en geen rechtsgrond aanvoeren, mag men er van uitgaan dat zij de toepassing van het recht volledig aan de rechter overlaten. De rechter is er in dat geval dan ook niet toe gehouden de partijen, met het oog op de eerbiediging van hun recht van verdediging, toe te laten tegenspraak te voeren over de rechtsgrond die hij dan uiteraard ambtshalve toepast. ${ }^{\text {I9I }}$ Het volstaat dat de feiten door de partijen konden worden besproken. ${ }^{192}$

Voor het overige moet de rechter echter het recht van verdediging niet alleen eerbiedigen wanneer hij de juridische omschrijving van de partijen ambtshalve kwalificeert ${ }^{193}$ of herkwalificeert ${ }^{194}$ of op de feiten die door de partijen in het bijzonder zijn aangevoerd ter staving van hun vordering, ambtshalve andere rechtsgronden toepast, ${ }^{195}$ maar ook wanneer hij uit de bijkomstige, terloops, toevallig of incidenteel vermelde feitelijke gegevens een juridisch feitelijk middel afleidt. ${ }^{196}$ Omgekeerd is het natuurlijk niet zo dat de rechter de heropening van de debatten zou moeten bevelen wanneer hij de gehele of gedeeltelijke afwijzing van de vordering laat steunen op feitelijke gegevens die aan zijn oordeel waren onderworpen. ${ }^{197}$ Evenmin schendt de rechter het recht van verdediging als hij zijn beslissing steunt op door de partijen aangevoerde feitelijke gegevens die weliswaar andere zijn dan die waarop de partijen hun vordering en verweer steunen, maar die hem tijdens een debat op tegenspraak zijn voorgelegd. ${ }^{198}$

\section{Het recht op verdediging kan op verschillende wijzen gevrijwaard worden.}

De rechter die vóór of tijdens de pleidooien tot de conclusie komt dat hij een incidenteel vermeld feit of een andere rechtsgrond zou willen betrekken bij zijn oordeelsvorming, kan de partijen uitnodigen daarover op de pleitzitting hun zienswijze

I9I Cass. I6 februari 2007, Arr. Cass. 2007, afl. 2, 4II; Cass. 30 september 2010, Arr. Cass. 2010, 2365; Cass. 30 januari 2014, C.I2.0305.N.

I92 Cass. I5 februari 2008, C.o6.or84.F.

I93 Maar de ambtshalve kwalificatie van een vordering tot het opleggen van een dwangsom zolang de verweerder de helft van de kinderbijslag niet terugstort, in een 'vordering tot betaling van een geldsom' miskent natuurlijk niet het recht van verdediging: Cass. 22 januari 2015, C.I3.0602.F.

I94 Maar de ambtshalve herkwalificatie van een erfdienstbaarheid in een recht van gebruik vormt op zich natuurlijk geen schending van het recht van verdediging: Cass. 30 januari 20I4, C.I2.0305.N.

I95 Cass. 3I januari 20II, C.IO.oI23.F: de feitenrechter besliste dat het misdrijf op grond waarvan schadevergoeding wordt gevorderd, niet bewezen is omdat het morel bestanddeel niet is aangetoond en de tekortkoming niet kan worden toegerekend aan de verwerende partij, zonder dat de verwerende partij dat had tegengeworpen en zonder de partijen de mogelijkheid te hebben geboden daarover tegenspraak te voeren; Cass. 22 maart 20I2, C.II.055I.N., concl. C. VANDEWAL; Cass. 27 juni 20I3, C.II.0508.F.: de partijen hadden enkel geconcludeerd over contractuele aansprakelijkheid, de feitenrechter besloot tot miskenning van de algemene zorgvuldigheidsplicht zonder dat aan de tegenspraak van de partijen voor te leggen.

I96 Wat een feitelijk uitstel betreft: Cass. 28 september 2009, Arr. Cass. 2009, I465, concl. A. HENKES.

I97 Cass. 2 februari 2010, S.09.0064.N.

I98 Cass. I2 oktober 2006, Arr. Cass. 2006, I988; zie over dit arrest ook nr. 53. 
kenbaar te maken of de zaak tot een latere datum uitstellen om hen de gelegenheid te geven dienaangaande hun standpunt bekend te maken. Hij moet dat zelfs doen als de partijen zelf niet expliciet daarom vragen. Ook het respect van het recht van verdediging behoort tot de taak van de rechter. Uit de rechtspraak van het Europees Hof voor de Rechten van de Mens zou men kunnen afleiden dat de rechter de partijen zelf de mogelijkheid moet geven een schriftelijke nota in te dienen.

Zijn de debatten al gesloten als de rechter tot dergelijk inzicht komt, dan kan hij ze heropenen. Hij kan daarbij een nieuwe pleit- of hoorzitting vaststellen of de partijen de gelegenheid geven geschreven opmerkingen te formuleren. ${ }^{199}$

Luidens artikel 756ter van het Gerechtelijk Wetboek kan de rechter tijdens dan wel vóór de pleitzitting ook voorstellen om de pleidooien te vervangen door een interactief debat. Indien de partijen daarmee instemmen, leidt de rechter het debat, waarbij hij de mogelijkheid heeft de partijen te oriënteren naar aangelegenheden die hij relevant vindt en die van aard zijn hem opheldering te verschaffen.

59. Welke van de hierboven geschetste wegen de rechter ook inslaat, het resultaat kan een kleinere of grotere vertraging van het proces meebrengen, wat, daarmee zal iedereen het eens zijn, zoveel mogelijk moet worden vermeden. ${ }^{200}$ Het respect voor het recht van verdediging zou m.a.w. bepaalde perverse effecten kunnen hebben als men het te ruim invult.

Daarom is het bv. begrijpelijk dat het Hof van Cassatie oordeelde dat het recht van verdediging niet werd geschonden door de feitenrechter die, steunend op feiten die in het debat waren, de door de partijen aangevoerde redenen aanvulde met een eigen interpretatie van die feiten, aangezien de partijen die feiten hebben kunnen bespreken. ${ }^{20 r}$

In een zaak waarin de feitelijke rechter de kwalificatie van het voorwerp van de vordering veranderde, besliste het Hof van Cassatie eveneens tot niet-schending van het recht van verdediging. De feitenrechter had het voorwerp van de vordering van een partij tot het verkrijgen van 2.500 euro schadevergoeding wegens tergend en roekeloos beroep en 900 euro rechtsplegingsvergoeding, geherkwalificeerd in de maximale rechtsplegingsvergoeding van 2.000 euro. Aangezien de tegenpartij zelf in haar conclusie voorstelde dat de vermeende schade door de rechtsplegingsvergoeding zou worden gedekt, heeft zij haar standpunt over een eventuele verhoging van een tegen haar uit te spreken rechtsplegingsvergoeding naar voren kunnen brengen, aldus het Hof. ${ }^{202}$

I99 Art. 775, eerste lid, Ger. W.

200 Een interactief debat heeft geen vertragend effect, maar de rechter moet zich zeker dan ervoor hoeden de rol van advocaat van een van de partijen op zich te nemen door te proactief haar aandacht te vestigen op feiten die niet (in het bijzonder) zijn aangevoerd of door haar te gul de rechtsgronden aan te reiken die haar advocaat eigenlijk had kunnen of moeten opwerpen.

201 Cass. 26 maart 2006, C.05.0360.F.

202 Cass. 27 september 2013, C.I2.038r.F. 
In een aantal arresten heeft het Hof die benadering samengevat in een formule: het algemeen rechtsbeginsel van het recht van verdediging wordt niet miskend wanneer een rechter zijn beslissing steunt op 'elementen waarvan de partijen, gelet op het verloop van het debat, mochten verwachten dat de rechter ze in zijn oordeel zou betrekken en waarover zij tegenspraak hebben kunnen voeren'. ${ }^{203}$ In het Frans heeft men daarvoor de term bedacht van 'moyens nécessairement dans la cause'. ${ }^{204}$

Het redelijke-verwachtingenpatroon van een advocaat van een partij zal wel niet voor iedere (advocaat van een) partij hetzelfde zijn, zoals men overigens redelijkerwijze ook niet van iedere rechter evenveel activisme zal mogen verwachten. De rekkelijken onder de rechters zullen vlug besluiten dat een advocaat had kunnen voorzien wat zij ambtshalve doen, de preciezen zullen vlugger een blinde vlek begrijpen en trachten te remediëren door de betrokkene vóór hun uitspraak een sprankeltje licht te gunnen. Waaraan men zich moet verwachten, is iets wat van geval tot geval en, waarom niet, van persoon tot persoon, moet worden bekeken. Bij twijfel moet het recht van verdediging primeren.

Ook in het Nederlandse recht, zo blijkt uit het preadvies van Asser, is de noodzaak verrassingsbeslissingen te vermijden de leidraad bij de toepassing van het beginsel van hoor en wederhoor. ${ }^{205}$

Een verregaande toepassing van de leer van de 'noodzakelijk in de zaak aan de orde zijnde middelen' levert een cassatiearrest van 5 december 20I4. De verwerende partij in cassatie had, tot bewijs van haar stelling dat zij tot een minder bedrag gehouden was dan de eisende partij vorderde, aangevoerd dat de laatste tijdens de periode van samenwonen ook zonder bijdrage te betalen het genot had gehad van de woning waarvan zij, de verwerende partij, eigenaar was, wat door de eiser niet werd betwist. Volgens het Hof van Cassatie liet de feitenrechter, door van het door de eiser gevorderde bedrag een woonstvergoeding af te trekken, zijn oordeel steunen op elementen waarvan de partijen, gelet op het verloop van het debat, zich konden verwachten dat hij die in zijn oordeel zou betrekken en waarover ze tegenspraak hebben kunnen voeren. De feitenrechter heeft het recht van verdediging niet miskend. ${ }^{206}$ Deze beslissing lijkt te ver te gaan: niet alleen had de verwerende partij geen tegenvordering gesteld tot het verkrijgen van een woonstvergoeding, bovendien is volgens het Hof van Cassatie geen sprake van schending van het beschikkingsbeginsel doordat de rechter het gevorderde bedrag verminderde met 'een billijke tegemoetkoming voor gratis bewoning'.

203 Cass. 29 september 20II, Arr. Cass. 20II, I984, concl. C. VANDEWAL; Cass. 25 maart 20I3, C.I2.0037.N; Cass. 5 december 20I4, RABG 2015, afl. 6, 397; Cass. 2 maart 2015, C.I4.0229.F.

204 J.F. VAN DROOGHENBROECK, 'Faire l'économie de la contradiction?' in P. MARTENS (dir.), Les droits de la défense, Brussel, Larcier, 20I4, p. 25 e.v., nrs. I3 e.v.

205 ASSER, onder 3.4.5.I.

206 Cass. 5 december 20I4, RABG 20I5, afl. 6, 397. 


\subsubsection{Aanulling van rechtsgronden door het Hof van Cassatie}

2Ibis. Zoals het Hof van Cassatie, mag de Hoge Raad een beslissing niet vernietigen wanneer tegen die beslissing geen cassatiemiddel is gericht. Wel kan de Hoge Raad op grond van een cassatiemiddel een uitspraak casseren met aanvulling van rechtsgronden, dus op rechtsgronden waarop het middel zich niet beroept.

Dat is niet zo in het Belgisch recht.

Overeenkomstig artikel ro8o van het Gerechtelijk Wetboek vermeldt het verzoekschrift in cassatie de wettelijke bepalingen waarvan de schending wordt aangevoerd. Het is dus aan de eiser in cassatie om aan te geven welke bepalingen door het bestreden arrest precies geschonden werden, wat in de praktijk niet altijd eenvoudig is. In burgerlijke zaken kan het Hof van Cassatie niet ambtshalve middelen (her)formuleren of aanvullen. De 'taakformule' die geldt voor de feitenrechter, is dus niet op het Hof van Cassatie van toepassing.

Niet alleen vult het Hof van Cassatie de als geschonden aangevoerde bepalingen niet aan, het gaf ook al blijk van een verregaand formalisme wanneer het cassatiemiddelen als onontvankelijk afwees omdat zij niet ook de schending inriepen van de regels die leiden tot de toepassing van de geschonden bepalingen. Op 29 maart 20II werd België omwille van een dergelijk arrest veroordeeld door het Europees Hof voor de Rechten van de Mens. ${ }^{207}$

Wanneer men het in het Belgisch recht heeft over substitutie van motieven door het Hof van Cassatie, wordt iets anders bedoeld dan de aanvulling van rechtsgronden waartoe de Hoge Raad kan beslissen. Het gaat om een vaste rechtspraak van het Hof van Cassatie dat, wanneer het dictum van een aangevochten beslissing gegrond is op een door het cassatieberoep bekritiseerde reden, het Hof die reden kan vervangen door een rechtsgrond waardoor het dictum van die beslissing wordt naar recht verantwoord. ${ }^{208}$ Niet de in het cassatiemiddel als geschonden aangevoerde rechtsgronden worden dus door het Hof van Cassatie vervangen, wel de door het cassatieberoep bekritiseerde reden van de aangevochten beslissing. Substitutie van motieven kan maar onder welbepaalde voorwaarden: (i) er moet een onwettige rechtsgrond in de aangevochten rechterlijke beslissing voorhanden zijn, (ii) de in te vullen rechtsgrond mag niet onverenigbaar zijn met een akkoord tussen de partijen om hem niet toe te passen, noch met het gezag van gewijsde van een andere beslissing gewezen tussen dezelfde partijen, (iii) die rechtsgrond moet vanzelfsprekend zelf volstaan om het dictum naar recht te verantwoorden en (iv) de invulling mag in geen enkel opzicht bestaan in een afleiding uit andere feitelijke gegevens dan die waarop het Hof van Cassatie vermag acht te slaan.

207 EHRM 29 maart 20II, RTBF t. België; B. VANLERBERGHE en J. VERBIST, 'Artikel Io8o van het Gerechtelijk Wetboek en de verplichte vermelding van de geschonden wettelijke bepalingen in het middel tot cassatie: een excessief formalisme?', in Liber spei et amicitiae. Ivan Verougstraete, Gent, Larcier,20II, II7-I32.

208 Cass. I9 maart, 4 mei en I4 juni I984, Arr. Cass. I983-84, 930, II53 en I356; Cass. 27 juni I986, Arr. Cass. I985-86, I475; Cass. 22 mei 1987, Arr. Cass. 1986-87, I300; Cass. I9 juni 1989, Arr. Cass. I98889, I249. 


\subsubsection{Dwingend recht en openbare orde}

\subsubsection{Inleiding}

6o. Uit de 'taakformule' blijkt dat het aanvullen van rechtsgronden niet langer in het teken staat van het suppletief, dwingend of van openbare orde zijn van de rechtsgrond, maar zaak is van de feiten in het geding. ${ }^{209}$ De verplichting voor de rechter het recht toe te passen en de aangevoerde rechtsgronden of rechtsregels ambtshalve aan te vullen of te vervangen door andere, geldt ook wanneer de ambtshalve door te voeren kwalificaties en middelen op te werpen niet van dwingend recht of openbare orde zijn, maar slechts van aanvullend recht. De vrijheid die de rechter heeft bij de aanvulling van de rechtsgronden, wordt volgens de 'taakformule' van het Hof van Cassatie bepaald door de feiten waarop hij die rechtsgronden steunt. Steunen de nieuwe motieven op feiten waaruit de partijen rechtsgevolgen hebben afgeleid, dan hebben de partijen die 'in het bijzonder' aangevoerd en is de rechter verplicht de nieuwe rechtsgrond op te werpen. Gaat het slechts om bijkomstige feiten, die gewoon, toevallig, terloops of incidenteel zijn vermeld dan beschikt hij over de mogelijkheid dat te doen. ${ }^{210}$

Bij het uitvoeren van die taak mag de rechter, met eerbiediging van het recht van verdediging, de toepassing opwerpen van bepalingen van openbare orde, ook al zijn die strijdig met een tussen de partijen tot stand gekomen uitdrukkelijk procedureakkoord. Het openbareordekarakter van een wettelijke bepaling staat de rechter echter niet toe op die gronden het voorwerp van het geschil zoals dit door de partijen werd afgelijnd, te wijzigen ${ }^{21}$. Het arrest van 28 september 2012 waarbij het Hof van Cassatie in die zin besliste gaf, overweegt het Hof vooreerst dat wanneer de partijen het geschil beperken tot de uitvoering van de overeenkomst en de rechter de vordering tot nakoming van de overeenkomst afwijst op grond van de nietigheid ervan wegens de strijdigheid met de openbare orde, hij niet het voorwerp van de vordering wijzigt, maar de bepalingen van openbare orde toepast die de partijen hebben willen uitsluiten. Maar de feitenrechter ging in deze zaak in deze zaak veel verder. In een tussenarrest had hij ambtshalve de vraag opgeworpen of de tussen de partijen gesloten bouwovereenkomsten niet waren aangetast door nietigheid op grond van de Woningbouwwet en had hij het debat heropend om de partijen toe te laten hierover conclusies te nemen. De partijen hadden daarop verklaard dat geen van hen de nietigverklaring van de overeenkomsten nastreefde. De feitenrechter had zich in die omstandigheden ertoe moeten beperkten de nietigheid van de overeenkomsten vast te stellen en de vorderingen tot nakoming ervan af te wijzen. Maar hij verklaarde ook de overeenkomsten nietig, gelaste een gerechtsdeurwaarder met het ambtshalve gegeven bevel om het arrest van nietig verklaarde eigendomsoverdracht op het hypotheekkantoor over te schrijven en veroordeelde de verwerende partij tot terugbetaling van de eisende al betaalde prijs. Daardoor

209 J. VAN DONINCK, 'Ambtshalve aanvulling van rechtsgronden: een tour d'horizon' in M. PIERS, H. STORME en J. VERHELLEN (eds.), Liber Amicorum Johan Erauw, Antwerpen, 20I4, Intersentia, nr. 8.

2 Io Zie de nrs. 49 en 50.

2 II Cass. 28 september 20I2, C.I2.0049.N., concl. C. VANDEWAL. 
miskende hij volgens het Hof van Cassatie het beginsel van de autonomie van de procespartijen.

\subsubsection{Ambtshalve vernietiging van rechtshandelingen}

6r. Zowel het Nederlandse als het Belgische recht maken een onderscheid tussen 'dwingende' en 'aanvullende' rechtsregels, waarbij het onderscheid zich situeert op het niveau van de contractvrijheid. Het Belgisch recht verdeelt het dwingend recht sensu lato in regels van openbare orde, die het algemeen belang beschermen, en regels van dwingend recht sensu stricto, die slechts particuliere belangen beschermen. Via de artikelen 6, II3I en II33 van het Burgerlijk Wetboek begrenst de openbare orde de contractvrijheid en stelt zij de limieten vast waarbinnen rechtshandelingen geldig zijn en uitwerking kunnen krijgen.

Hoewel dat niet uitdrukkelijk in de wet is bepaald, geldt traditioneel als uitgangspunt dat een rechter de aantasting van een overeenkomst door een grond van absolute nietigheid ambtshalve moet opwerpen. ${ }^{212}$ Uit het beschikkingsbeginsel en ultra petita-verbod volgt dat de rechter een overeenkomst in geval van strijdigheid met de openbare orde (of de goede zeden) niet ambtshalve mag vernietigen, maar enkel ambtshalve moet opwerpen dat de overeenkomst door een nietigheidsgrond is aangetast, en het beroep van een partij op die overeenkomst moet afwijzen.

Traditioneel was het onderscheid openbare orde (absolute nietigheid) - dwingend recht (relatieve nietigheid) relevant voor de taak van de rechter. Doordat hij de regels van openbare orde ambtshalve moest toepassen en bijgevolg de absolute nietigheid moest opwerpen voor rechtshandelingen die daarmee in strijd zijn m.b.t. andere regels mocht hij dat niet ambtshalve. De toegenomen aandacht voor de rechtsbescherming van de zwakkere partijen in de loop van de twintigste eeuw - in dat verband verrichtte de wetgeving die allerlei soorten werknemersbescherming invoerde, overigens pionierswerk - en de wijziging van de rechtspraak van het Hof van Cassatie inzake nieuwe middelen, hebben samen met de rechtspraak van het Hof van Justitie, die de nationale rechters verplicht ambtshalve bepaalde Europese regels toe te passen, een grote invloed gehad op de taak van de rechter. ${ }^{213}$

Zo als de Nederlandse rechter, is de Belgische rechter tegenwoordig een 'actieve' rechter. Van de geschillenbeslechter die hij ooit was, is hij een 'activist' geworden die bijdraagt tot de rechtsbescherming van de zwakkere partijen door ambtshalve rechtsregels toe te passen. Concreet doet hij dit door de juridische aard van de feitelijke gegevens die partijen aanvoeren, te onderzoeken, waarbij hij de ingeroepen rechtsregels kan aanvullen of wijzigingen ongeacht de juridische omschrijving die de partijen eraan gegeven hebben. De aard van de toe te passen rechtsregel is in dat

2 I3 F. PEERAER, 'De verhouding tussen openbare orde en dwingend recht sensu stricto in het Belgische verbintenissenrecht', in TPR 2013, 2756, nr. 52 e.v. 
kader van geen belang: indien dat vereist is door de feiten die de partijen specifiek ter ondersteuning van hun beweringen hebben aangevoerd, is de rechter verplicht de relevante regels van openbare orde, van dwingend recht of van aanvullend recht toe te passen. Het Hof van Cassatie makt in zijn 'taakformule' inderdaad geen onderscheid naargelang de toepasselijke rechtsregels van openbare orde of van dwingend recht zijn. Ook een relatieve nietigheidsgrond zal de rechter overeenkomstig de 'taakformule' kunnen opwerpen. Bij de uitvoering van die taak blijft de rechter uiteraard gebonden aan het beschikkingsbeginsel en het recht van verdediging.

Zoals hierboven al werd gezegd, kunnen de partijen door een uitdrukkelijk procedureakkoord de rechter binden over een punt in feite of in rechte waartoe zij het debat willen beperken. Die mogelijkheid tot 'uitsluiting van betwisting' is echter niet absoluut en dringt zich niet op aan de rechter wanneer de betrokken rechtsregel van openbare orde is. ${ }^{214}$

Ook wanneer de openbare orde betrokken is, mag de rechter enkel oordelen op grond van de feiten die regelmatig in het debat zijn voorgelegd en dient hij zich te houden aan het voorwerp van de vordering. Hij vermag de rechtsonderhorige niet te hulp te schieten door hem een voordeel toe te kennen dat hij niet heeft gevraagd. Behalve wanneer de wet hem beveelt ambtshalve uitspraak te doen, vermag de rechter niet meer toe te kennen dan wat gevorderd werd, zelfs wanneer de bepaling die de zaak toekent van openbare orde is. ${ }^{215}$

\section{Hoofdstuk 4. Een aantal afrondende opmerkingen}

62. Heeft in Nederland de wetgever de contouren van het rechterlijk optreden bepaald, in België blijft men daarvoor vertrouwen op de rechtspraak van het Hof van Cassatie. Ik ben er niet van overtuigd dat het beter is een aangelegenheid als deze vast te leggen in een wettekst. Als dit preadvies iets aantoont, is het wellicht hoe moeilijk het is de contouren te omschrijven van de rechtsstrijd waarbinnen de rechter zich actief mag bewegen. De taak van de rechter is bovendien een evolutief gegeven, waarvan de omschrijving verfijnd kan worden van de rechtsstrijd naar gelang van het voortschrijdend inzicht dat de soms zeer onderscheiden zaken met zich brengen (en is geworden).

De taak, zo men wil: de macht, die het Belgische Hof van Cassatie aan de rechter heeft gegeven met zijn 'taakformule', lijkt ruimer dan die welke de Nederlandse rechters van de wetgever kregen. Of dat een goede zaak is, hangt af van het gebruik dat de Belgische rechters van die macht zullen maken. De 'taakformule' is nog te recent en te onvolledig om daarop al een zicht te krijgen.

2I4 Zie nr. 34.

215 Cass. I4 februari 20II, Arr. Cass. 20II, 492. 
63. Dat brengt mij bij mijn laatste bedenking: de 'taakformule' is onvolledig. Dat is niet noodzakelijk een kritiek want het Hof van Cassatie moet zich natuurlijk maar uitspreken over dat aspect van de rechterlijke opdracht dat in een bepaalde zaak aan de orde is. Maar los daarvan 'ontbreekt' het in de formule wat aan duidelijkheid over wat de rechter kan, mag en eventueel moet doen m.b.t. de 'oorzaak' van de vordering.

Daarom sluit ik af met een herneming van de formule van het cassatiearrest van I4 december 20I2, die dezelfde is van een arrest van 5 december $2015,{ }^{216}$ aangevuld met het aspect van de 'oorzaak' van de vordering. ${ }^{217} \mathrm{Ik}$ toets die aan de Nederlandse vertaling van een origineel in het Frans geredigeerd arrest van 27 september 2013, wat duidelijk maakt hoe belangrijk de juiste woordkeuze wel is. ${ }^{218}$ En uit aanmatiging, vermetelheid en overmoed, die altijd vóór de val komen, verstout ik mij meteen hier en daar een kleine aanpassing te suggereren die in mijn ogen een 'verbetering' inhoudt. Het resultaat luidt:

'De rechter is gehouden het geschil te beslechten overeenkomstig de daarop van toepassing zijnde rechtsregels. ${ }^{219} \mathrm{Hij}$ moet de juridische aard [ik zou toevoegen: 'en impact', want het gaat over meer dan kwalificatie] van de door de partijen aangevoerde ${ }^{220}$ [ik zou toevoegen: 'en uit de regelmatig overgelegde stukken blijkende'] feiten en handelingen [ik zou schrijven: 'feitelijke gegevens', om duidelijker ook houdingen en toestanden in te sluiten] onderzoeken, en mag, ${ }^{221}$ ongeacht de juridische omschrijuing die de partijen daaraan hebben gegeven [ik zou toevoegen: 'of de rechtsgevolgen die zij daaraan hebben vastgeknoopt', want het gaat niet altijd om omschrijvingen], de door hen aangevoerde redenen ${ }^{222}$ [ik zou schrijven: 'rechtsgronden'223] ambtshalve aanvullen [ik zou toevoegen: 'wijzigen of te vervangen', want het gaat om meer dan louter aanvullen] op voorwaarde dat hij geen betwisting ${ }^{224}$ opwerpt waarvan de partijen bij conclusie ${ }^{225}$ het bestaan hebben uitgesloten, dat hij enkel steunt op elementen ${ }^{226}$ die

2 I6 Cass. 5 december 20I4, RABG 20I5, afl. 6, 397.

217 Zie voor een aanvulling in die zin ook A. HENKES, concl. vóór Cass. 28 mei 2009, Arr.Cass. 2009, afl. 5, I48I.

2 I8 Cass. 27 september 2013, C.I2.038I.F. Die vertaling gebruikt, in tegenstelling tot het arrest van I4 december 20I2, terecht mits niet als een voorzetsel, wat het niet is, maar als een voegwoord.

2I9 Die eerste zin ontbreekt in het arrest van 27 september 2013. Een regressie naar (I4 april) 2005 zie nr. 5 ?

220 In de Nederlandse vertaling van het arrest van 27 september 2013 staat: 'de voor hem gebrachte eisen', wat minder goed is: hij moet niet zozeer of alleen de eis, d.i. de vordering, onderzoeken, maar de feitelijke gegevens.

22I In de Nederlandse vertaling van het arrest van 27 september 2013 staat kan, wat niet juist is. Hij kan natuurlijk altijd, maar hij mag niet.

222 In de Nederlandse vertaling van het arrest van 27 september 2013 staat deze, daarmee 'de voor hem gebrachte eisen' bedoelend. Dat is een gevaarlijke formulering, want de eis, de vordering, heeft een voorwerp en dat mag de rechter natuurlijk niet aanvullen.

223 In het nochtans zeer uitgebreide De Valks juridisch woordenboek komt reden niet voor als rechtsterm, rechtsgrond wel. Zie DIRIX, tw. vordering. Volgens Van Dale betekent het in het algemeen Nederlands gewoon argument, beweeggrond of motief. Maar die kunnen ook van feitelijke aard zijn en die kan de rechter uitgerekend niet aanvullen.

224 In de Nederlandse vertaling van het arrest van 27 september 2013 staat 'geen enkel geschil opwerpt', wat niet goed past bij het werkwoord.

225 De woorden 'bij conclusie' komen niet in voor de Nederlandse vertaling van het arrest van 27 september 2013, die op dit punt dus minder precies is.

226 '..grondt op elementen' zegt het arrest van I7 september 2013 in zijn Nederlandse vertaling. 
hem regelmatig zijn voorgelegd, ${ }^{227}$ dat hij het voorwerp van de vordering niet wijzigt en dat hij daarbij het recht van verdediging van de partijen niet miskent. Hij heeft de plicht ambtshalve de rechtsmiddelen ${ }^{228}$ [ik zou schrijven: rechtsgronden] op te werpen waarvan de toepassing geboden is door de feiten ${ }^{229}$ [ik zou schrijven: feitelijke gegevens] die door de $e^{230}$ partijen in het bijzonder worden aangevoerd tot staving van hun eisen. Dit houdt niet in dat de rechter gehouden is alle in het licht van de vaststaande feiten [ik zou schrijven: feitelijke gegevens] van het geschil mogelijke, doch niet-aangevoerde rechtsgronden [ik zou schrijven: rechtsregels, want een rechtsgrond is precies een reden die men inroept en dus aanvoert] op hun toepasselijkheid te onderzoeken, doch enkel dat hij, mits [ik zou schrijven: met want mits is een voegwoord, geen voorzetsel] eerbiediging van het recht van verdediging, de toepasselijkheid dient te onderzoeken van de niet aangevoerde rechtsgronden die zich door de feiten [ik zou schrijven: feitelijke gegevens] zoals zij in het bijzonder worden aangevoerd, onmiskenbaar aan hem opdringen'. ${ }^{23}$

Maar nog liever zou ik 'met eerbieding van het recht van verdediging', dat nu enkel vermeld wordt in verband met het aanvullen of wijzigen van de rechtsgronden, vervangen door een meer volledige omschrijving:

'De rechter moet altijd en in alle omstandigheden het beginsel van de tegenspraak doen in acht nemen en zelf in acht nemen.

Hij mag in zijn beslissing enkel rekening houden met de middelen, toelichtingen en stukken ingeroepen of voorgelegd door de partijen als die in staat zijn geweest daarover tegenspraak te voeren.

Hij mag zijn beslissing maar steunen op de middelen van recht die hij ambtshalve opwerpt als hij vooraf de partijen heeft uitgenodigd daarover hun opmerkingen naar voren te brengen'.

227 Het arrest van 27 september 2013 voegt eraan toe 'ter beoordeling' zijn voorgelegd. Dat zou tot betwisting aanleiding kunnen geven: incidenteel of terloops aangevoerde feiten worden uiteraard niet 'ter beoordeling' voorgelegd.

228 Het arrest van 27 september 2013 zegt zelfs: 'alle rechtsmiddelen'.

229 In het arrest van 27 september 2013 staat: 'geboden is door alle feiten'. Dat zou impliceren dat rechtsregels waarvan de toepassing zich slechts opdringt door een of meer feiten, niet ambtshalve moeten worden opgeworpen.

230 Ik weet dat het de gewoonte is het lidwoord weg te laten, maar vind dat geen goede zaak. Het lidwoord schrijven en uitspreken waar het hoort te staan, zal de hand niet verlammen en de mond niet doen scheuren.

23I Cass. I4 december 20I2, C.I2.00I8.N. De Franse vertaling luidt: 'Le juge est tenu de trancher le litige conformément aux règles de droit qui y sont applicables. Il est tenu d'examiner la nature juridique des faits et actes invoqués par les parties et peut, quelle que soit la qualification juridique que celles-ci leur ont donnée, suppléer d'office aux motifs invoqués dès lors qu'il n'élève aucune contestation dont les parties ont exclu l'existence dans leurs conclusions, qu'il se fonde uniquement sur des faits régulièrement soumis à son appréciation, qu'il ne modifie pas l'objet de la demande et qu'il respecte les droits de la défense. Il est tenu de soulever d'office les moyens de droit dont l'application est requise par les faits spécialement invoqués par les parties à l'appui de leurs demandes'. 